そ国動的と速をと

の際のでげなあは国

点的一あた発び言五

をに般っ今展るら経

明み的た日にの香済

らてなこで貢もでの

か、進と献当多

にど取、なし然な速

は

目

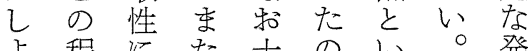

よ程に市十のい。発

弓度つ欧分から展

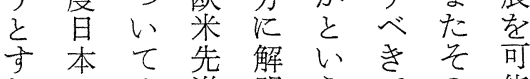

れには進明らでの能

ば独今国さ点あ意な

が 声䍴

迥笴

程

日な汇らてならでし

本もと近いる。明め

ののん代るとし治る

企でど的と、か 維要

業あ異なはこし新因

者つ論産いれ戦後の

活たは業いは前の一

動かな 技 難なの日行

のにい術い吕旦本が

基つ举経明吕本少々

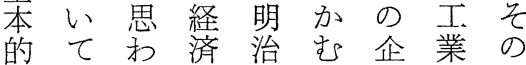

性は制期章化国

格必度の南過に

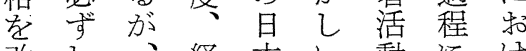

改し、経本い動に汀

めむし営の閣が特る

て十加組企題具汀企

再分乙織業で体る業

検なとを家あ的企者

討回 5 熱㤎り、に 業 活

乙答乙心、心者動

て吕たに近経か活の

み与日導代営な動積

な克本文産史る の極

方の乙業的点市性

れれ企たの研にり

ばて業こ建究和方と

ない者々設㤎い方の

らる活なに飛て内有

なお動どき躍 日外効

々 汗の、当的本学性

なで積企めな経界に

るは極業て 発済の市

○な性者積展急主る 
経営史 学

因心家動 ド が 明てい勢 ろに会の同動

の的㤎様 合々 個式

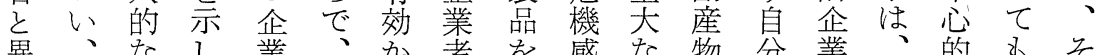

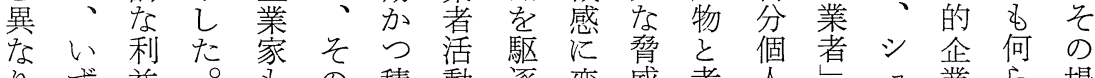

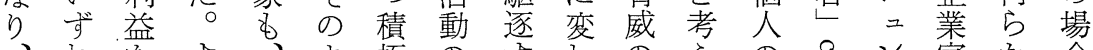
こるれ 考古

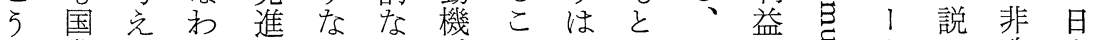

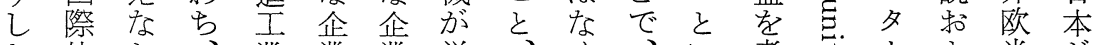
た比か、業業業単、く、考艺、1よ米方 主較つ欧国者経にす、尊 5 坣字がび的ア 観にた米イ活営利な富主わる想ヨ要

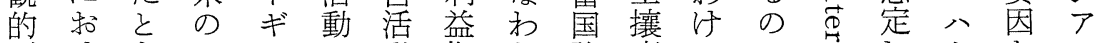

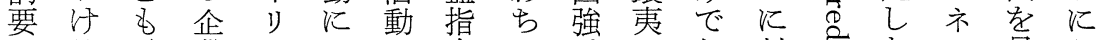

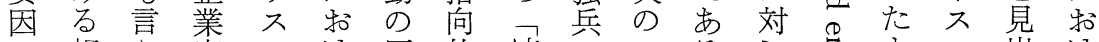

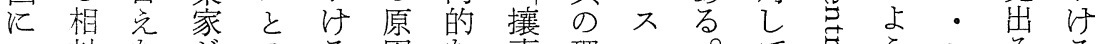

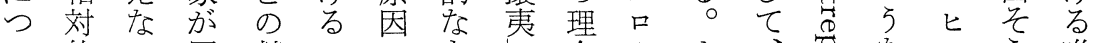

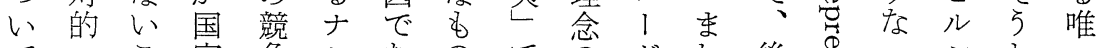

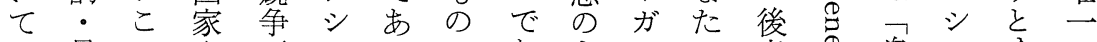

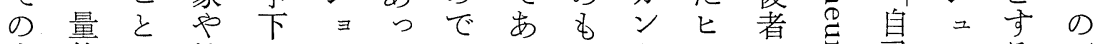

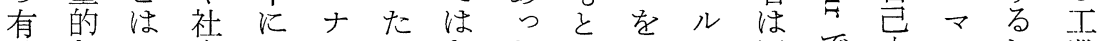
效ない会拈りこなたにいシ国で中ヤわ業

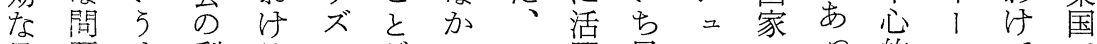
量題ま利るム台つと躍早マ・つ的のでで

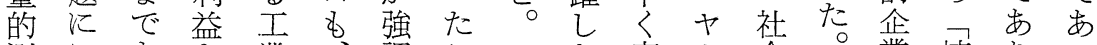

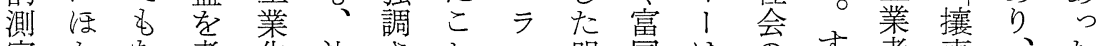
定かな考化決さと二明国は密す者夷、た

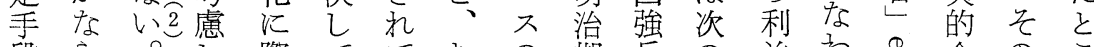

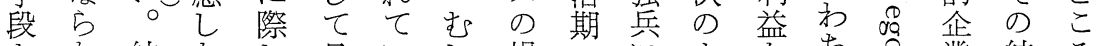

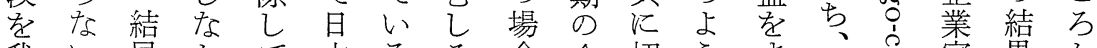
我い局かて本る ら合企切 5 先前家果か

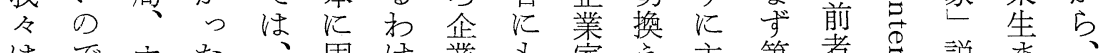
はでナた、固け業す家学主第者学説市、

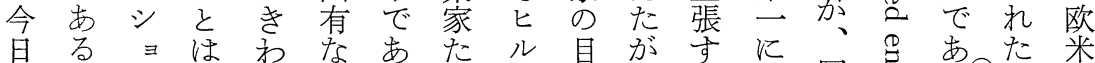

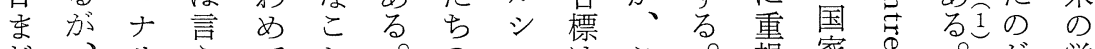

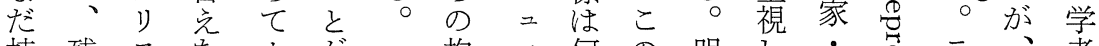
持残スなナが抱、何の明し ち念テいシらいヤ方治、社导二グた

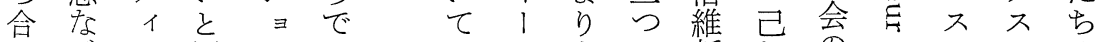
わがッ同ナはののもの新独利でにタ情 せ ら、ク 時 リ な

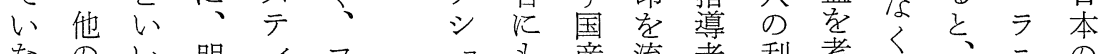
なのい明ィフ多産流者利考、、、二の い経、治ッラナ、品れ蚻益虑明ス企

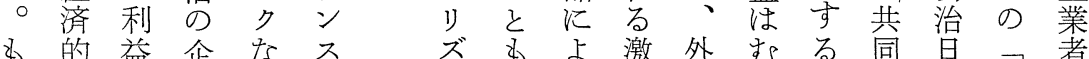

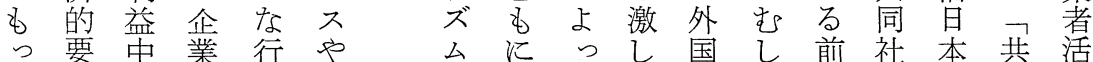


をつ説のるッ⿻コ一 量と

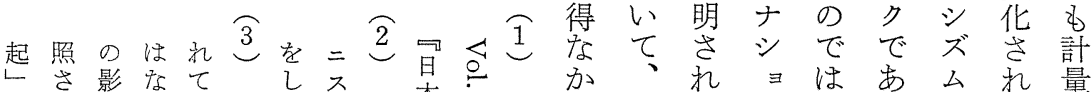

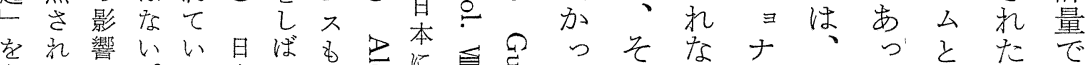

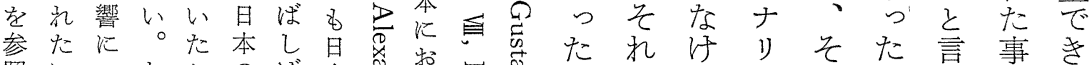

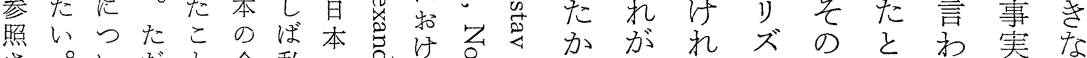

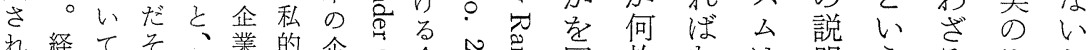

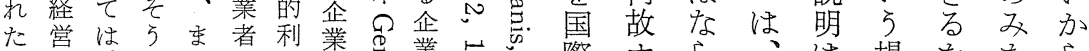
い史、乙た活益家怘業若:際ナら、は場ををる

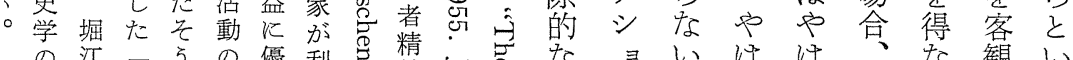

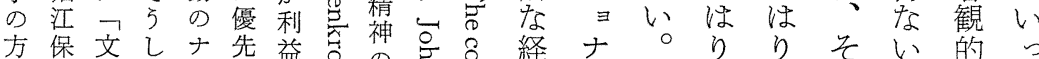

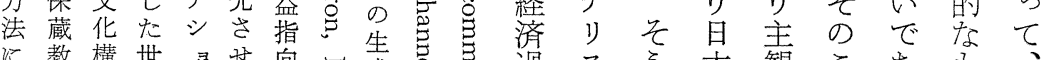

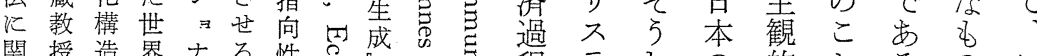

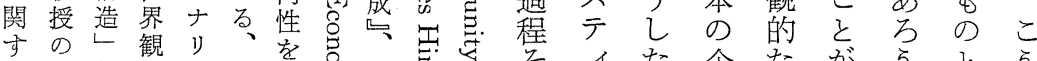

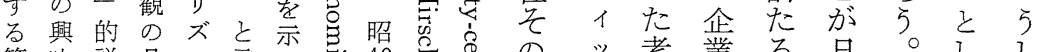

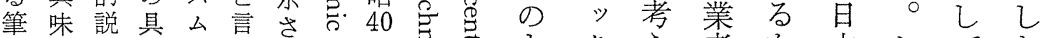

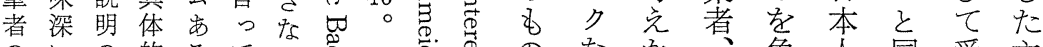

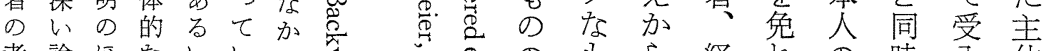

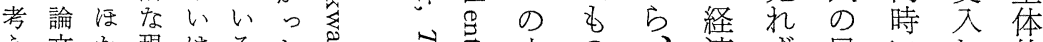

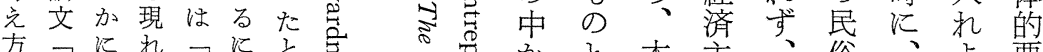

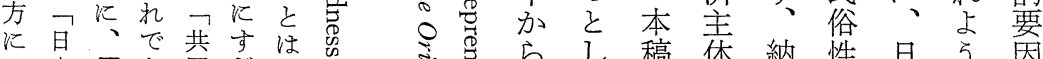

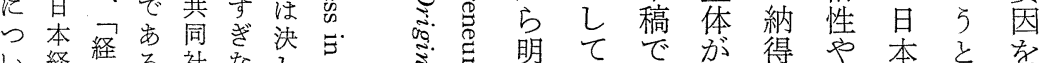

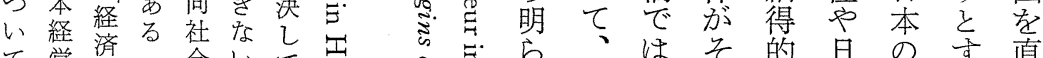

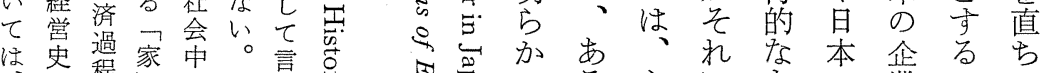

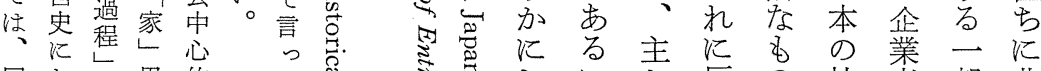

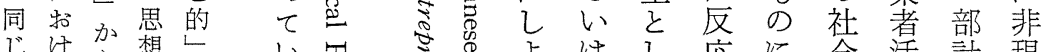

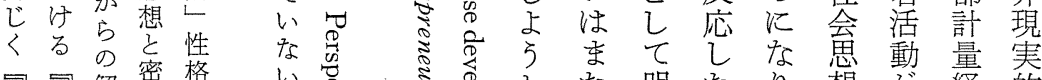

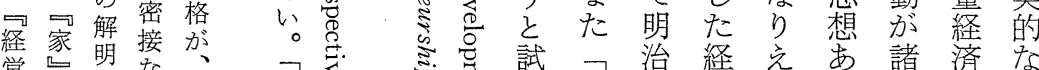

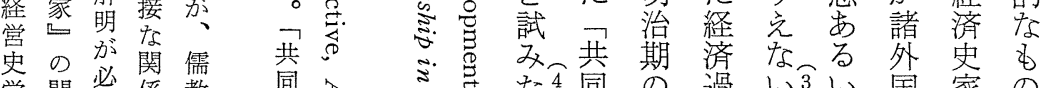

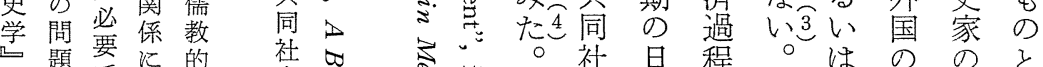

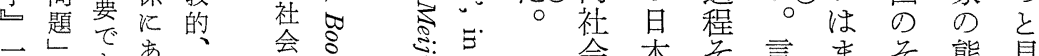

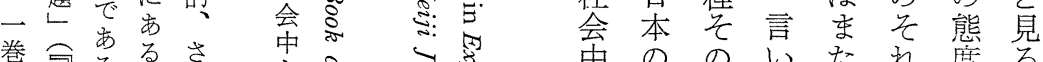

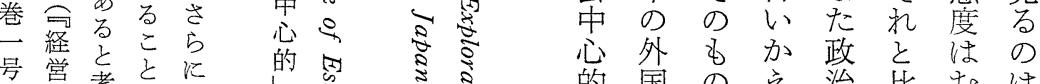
の史考をは事的国の党治比导

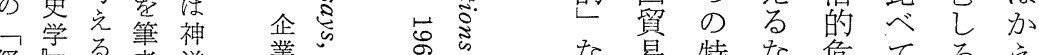
経匹る者道業心

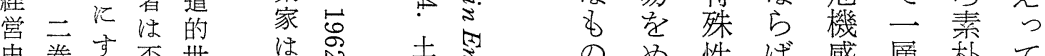
史巻す否世思臀等層朴て 学至ぎ定界国の剭怘とぐと現

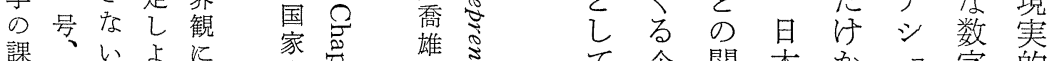

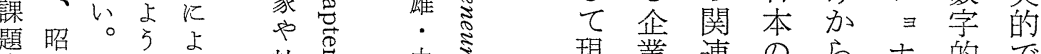

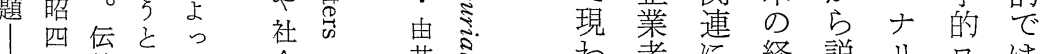

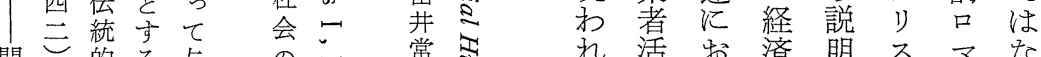

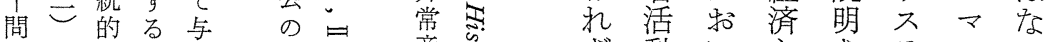

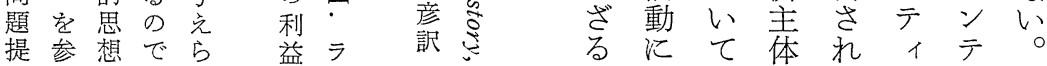


経営史 学

差強条染的て 模生でザ

は力件常諸名で産、ンと

個5 ま 件進企い進・

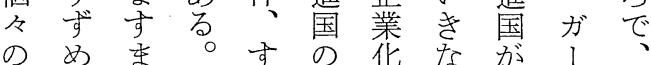

企るすすな製はり永シ明

業こ之なお点後大年治

者々しわらと進規がンの

のがくら、競国模がク企

個でな後資争工江っ口業

人きる進本す業開てン家

主なわ国、る化始開に方

義いけに市このす発よと

的限でな場と不るとつれ

なり、れ标可こたて、に

活、そば言不久と最提対壬

動後のな 5 可なが新出応デ

に進国るに能前で工さしル

よ国際㭱及で提さ業れた

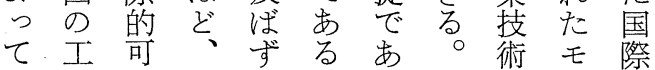

は業能急、的

到化性速熟し、み同儿経

底注々な練かそな様で済

5 一国工労るれら先市過

ず歩内業働になず進ら程

め的化力、く、国 5 の

得進条の、ししが。特

な展件た技方七の蓄同殊

いしと め 術、は国積 教性

もなのの者近、際乙授学

のい間国息代後水た情

で○の際企的進準資言党

あと大的業業国に本

りこき可者業の括と版

、ろな能性生工学後際

業ぞギ性能産業る輸進し

化のッよど大品新しは、

のよプり規は技、そ最

程

度に何き進に外の机工参

汇らい国開い導に業考

応きかの注始ず入よ化に

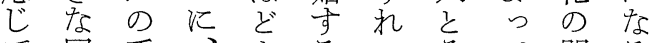

て国手、古るの兵て 開る

、際段々りた市の近始の

あ的にの文め場国代点は

る経よ国しのに際的浪ア

小済っ内い国拈的工括レ

は較て的の内い規業いク

わだ、点印で

れ不をの発

る十考た表本

。分慮的乙稿

会なに実たは

員ま入現亦昭

諸まれしの和

氏 正なの四

か経、加一

ら営日っ訳年

の史本たで九

ご学の就

吡経会り東

正に営議、京

を発史の篠で

扣表学祭原開

願与界、思

いるへ堀代れ

寸こ提江平た

ると出保・

次にす蔵藤豆

第なる、野

でっにへ正苛

る。郎品

何わ１編尺

分し. 可总

も論 ゾ本 す

日文ウの

本に経○

史書 キ済

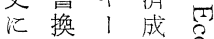

素克々長导

人たのに异

でい他分究。

あと諸四の

る考教四。

む光授 三

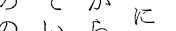

議た有收録

論㤎益録

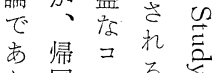

り国メる文

、後ン筈

問時トで

題間があ芯

のに古っ

点恵りた

多ま多方罗

いずれ筆哥

之、 5 者兽 
と府 対性なれ推 ら国史的性 て シ ナ 導 銀 この比をいば進か際研しとたみニシ理行 ろ経に損。な导に経究性のだるマ念方 が、済括 日動て と し 本が特な同わはとのの具括や決がテらい の積にく時汗個し特課体いしし日企は 場極重、にで人た殊題的てルて本ッ業政 合化視む、主口性でな明シ特のク者府

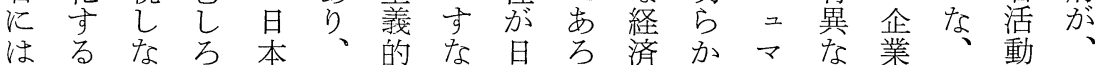

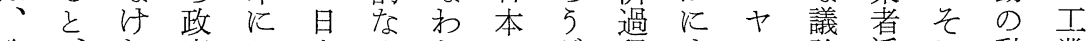

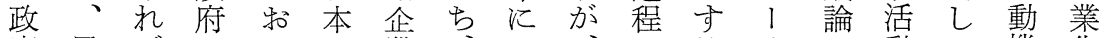
府民ばのいの業、括、とるはで動て 機化

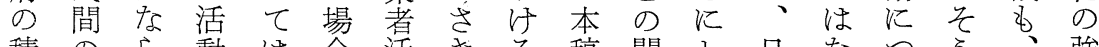

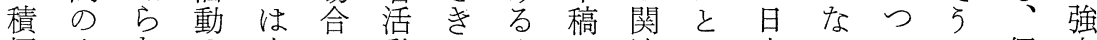
極企なほ中に動に企で連ぞ本いいい個力

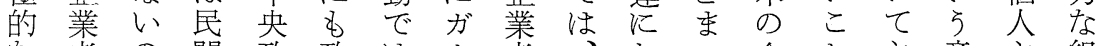
な者の間政政は！者、和つ、企と主意主組 経活はの 府府なシ活々いて業㤎張味義織 済動、企自驾く

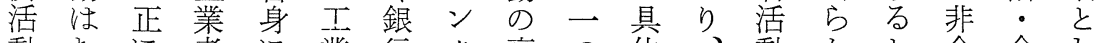
動生に者に業行ク高つ体、動加と合合し 阮しこ活よ化や口度の的明のにこ理理て 民るの動る の 政ン に試に治二なる 主主登 間様点に 積 組 府・文 論の 般る b義 義 場 部々で対極織にモ組と証企的で、的的し 門な あす 的主よデ織しさ業特あそななな にからるな体っル、化てれ者殊ろら性るけ

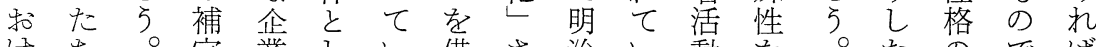
けら。完業しい借さ治い動を埾。たのでば

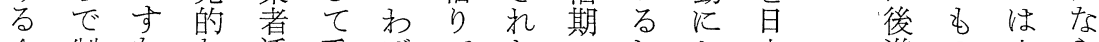

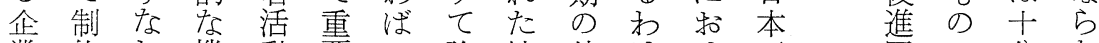

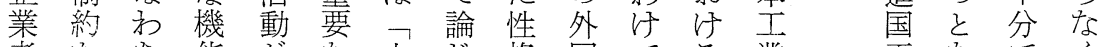
者をら、能㤎な上じ格国でる 業志なだく 活ら、尼役かた省貿はナナ化業らななな 動汓才終間割ら占不易なシの

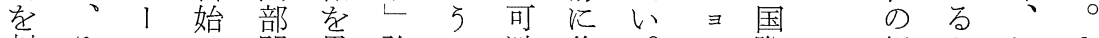
刺そスし門果強に避焦。ナ際経をむ文 激のトた汇另、的点こリ的済得した

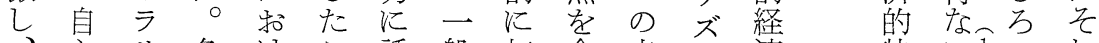
、主リ多汀こ誘般打合点公済特い令九れ そ性アくると導に出わ情当過殊、共に のをやの企はし後し毕、程性と。同伴 自㞃个後業今組進て主共の社っ

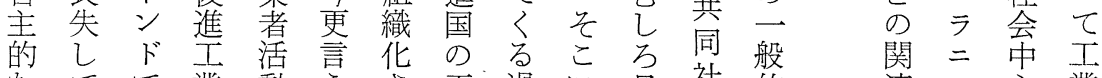
なてで業動 5 さ過に业社的連不心業 発いは国の李机業程拈本会な范や的化 展つ、自でな化を汗経中特拈七方

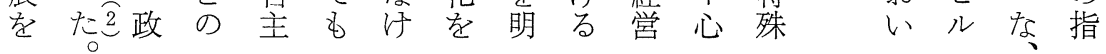


組なこは

織要の的一

化因大で八

さできに六

れあな高八

ざり国度年

る、際にの

を日的進日

光本較行本

なの差しは

企方、基

っ業戦や本

た者前が的

の活のて動日

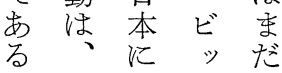

○日 グ小

本 組・農

が織ビ民

近化 ジと

代さ乎

産れ 机正

業たの業

社企時者

会業代

の. 活 始で

飛動实市

躍上万う

を

ᄂ 苞. と

㭼呑て 当

る $\stackrel{9}{\leftrightarrows}$ た

め总日1

に号本口

最皇先パ

初导進や

らを業メ

き生国り

わ文文

め出ので

てし間は

大たに産

規 直 拉 業

模接计革

湟的る 命
強可

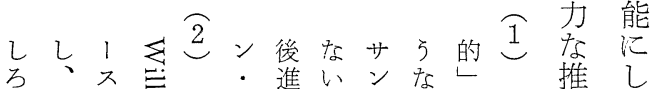

民そト晋政 モ経が・表々以進た

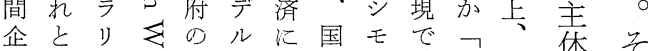

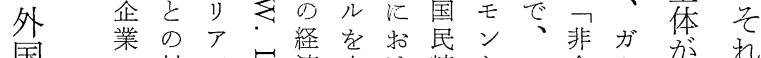

国の対でら済中情主サ合!音机

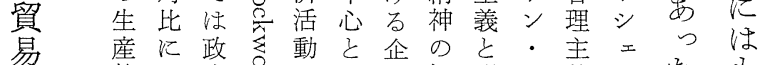

組物招府吕の乙業振明シ義ンたも

織のい事口補て者興治乇的》と号

の 購て、業产完| 活と易

欠者日拡呑なしのらの義か教心゙経

如々本大气 役合非二ナない授き済

て

の政字灾つ学性機ナ例現説市条

面府に心

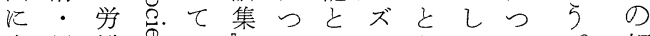

大民働退は匹いいムりてい。相

き間力.. 二てうがないて そ異

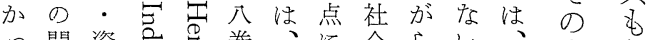

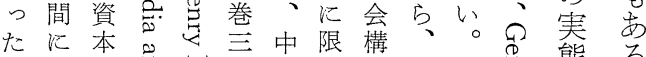

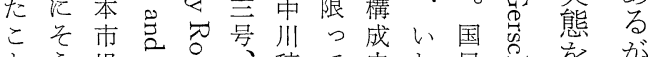

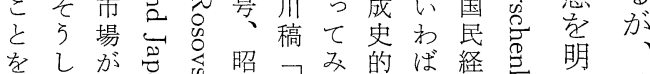

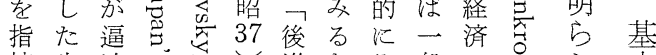

摘生迫。進な及般の马加本

乙産乙可参国 $5 \tau$ 的将。V的

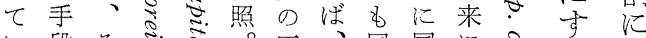

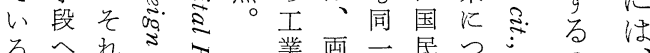

るへれさ寻業両一民口ざるは

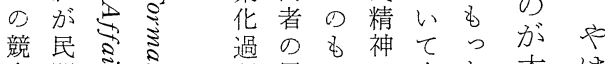

合間怘怘程思のの広と本ほ

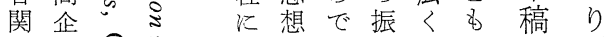

係業○芯招的あ興国ガの民

がの导る け機る老民1 中間

な自惫怘る能、問のシ心部

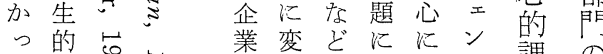

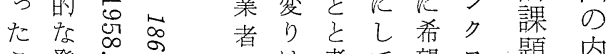

こ発 $\infty^{\infty}$ 活は考七望口題内

々展口告動な党いのうで部

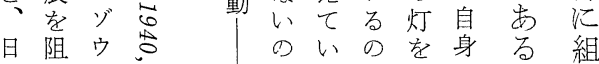

本害ス。学でるでとはと織

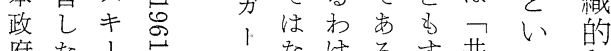

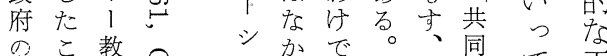

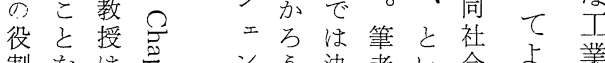

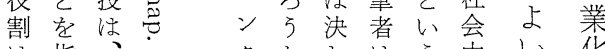

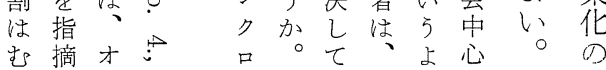


のば貿たこず的の外い国定殊もま

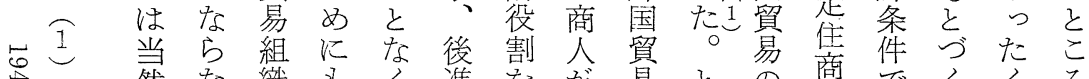

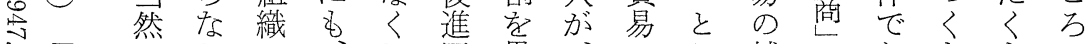

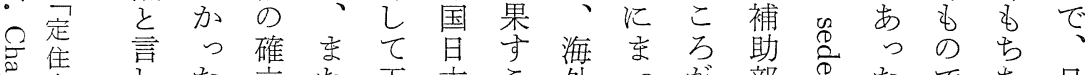
密商わた立た百本こ外つが部㣽たであ日

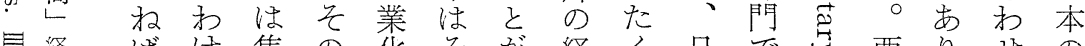

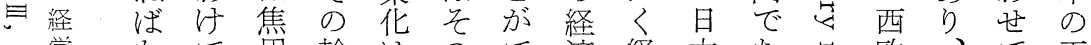

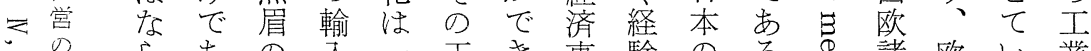

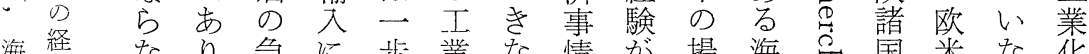
運党なり、急に歩業な情忐場海番国米な化

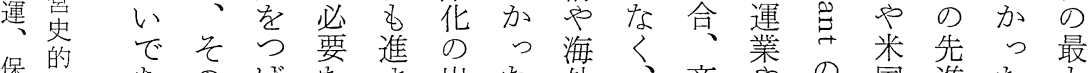
保意市のげなな出た外、商やの、国進たす 䧝義乃たた外な発のにる人海、の諸、顕

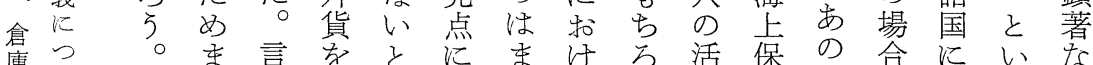

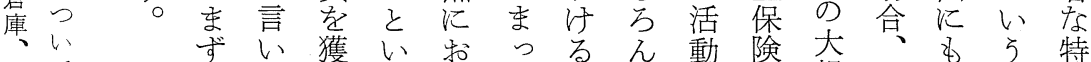
外飞外加得

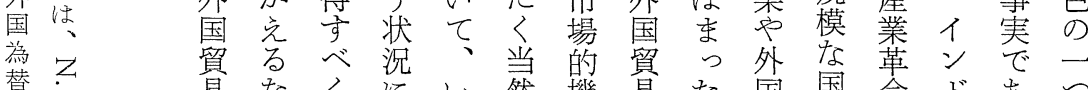
取 以

引 미

な゙

近

代

産

社 6

会言 る日茶ま大ないの市引躍立なこ本 企本の机規けて 組場業は成学れの 業はよた模れの織に㤎周数ジは商

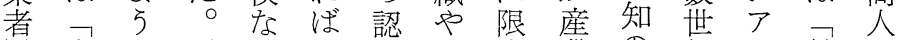
活商な近外な識技定業の紀の鎖忐 動業 在代国ら学術さ革と後国工 の革来産貿な次的命こわ進し業 組 命 産業易いく持て 前ろた諸と化

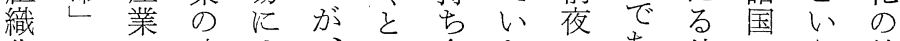

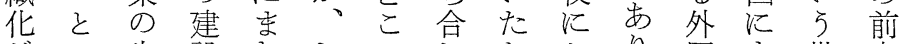

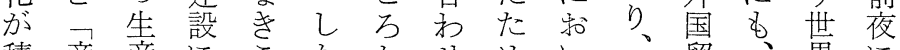

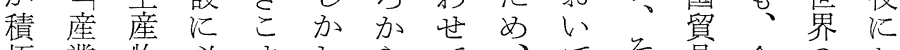

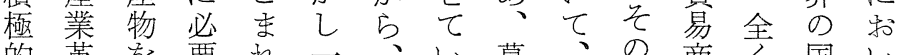

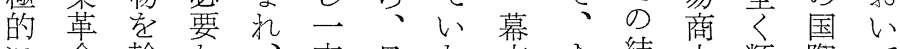
に命輸な 方日な条す結人類際て 推

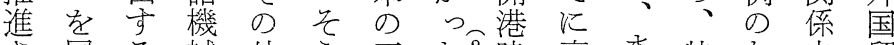
さ同る械外 5 匹 た包時高ま特な史貿 れ時にや国し業。の度たにい上易 るにも原貿た化々日な欧経日学市の こ遂、料易事にの本発米営本独経 と行有を情特よの展諸史工特験 に乙効輸成にいら商を国上業なる ななな入功もて遂でに化事組 つ外守拘主幕は将は言の情織 たれ国るるら導末末、て外方特にも 
八沿なな売商どけ

$\bigcirc$ 加契の品る

良っ 約制は横外八

俵くた芰産浜国八

になと基㤎地港貿年

W場こW邦生ら組、

て合でて人系輸織横

銀に外生売商出化浜

行は商糸込人さのの

融、達を商かれ最生

資勝

を手最商と生い市

受汇終のつ亲た試場

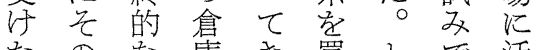

たのな庫き買とで程

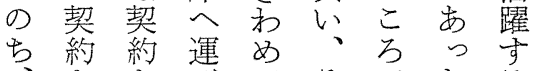

、ををでてとでたる

そ破导こ不れ生

の萧るま利を当䒺

う前せで居の時売

ちるに留輸生込

三こ自々っ地出系商

○と的たの業はた

○゙のにこ外務日

表可倉対之商は本に

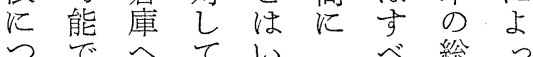

い亦運何ら売て輸て

てっびらまり居出

契たこので込留額連

約しま支も主地の合

を、せ払なしの荷荷

御中たいいこ外 $\bigcirc$ 扱

破に商も。之国!所

算は品行外音商四芯

す $\bigcirc$ 検わ達きのパ 創

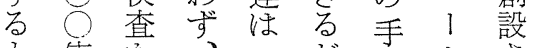

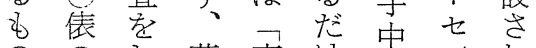

ののて 荷壳注に中ン机

も生、物远でに上た

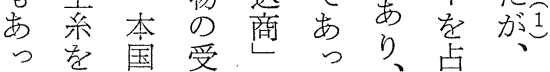

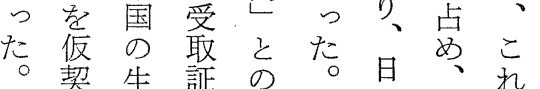

外約系等間こ本乞 は

商し市らのののの の

の、場発暫間佂本

倉乞の行定接売と作

庫の市し的貶込九特

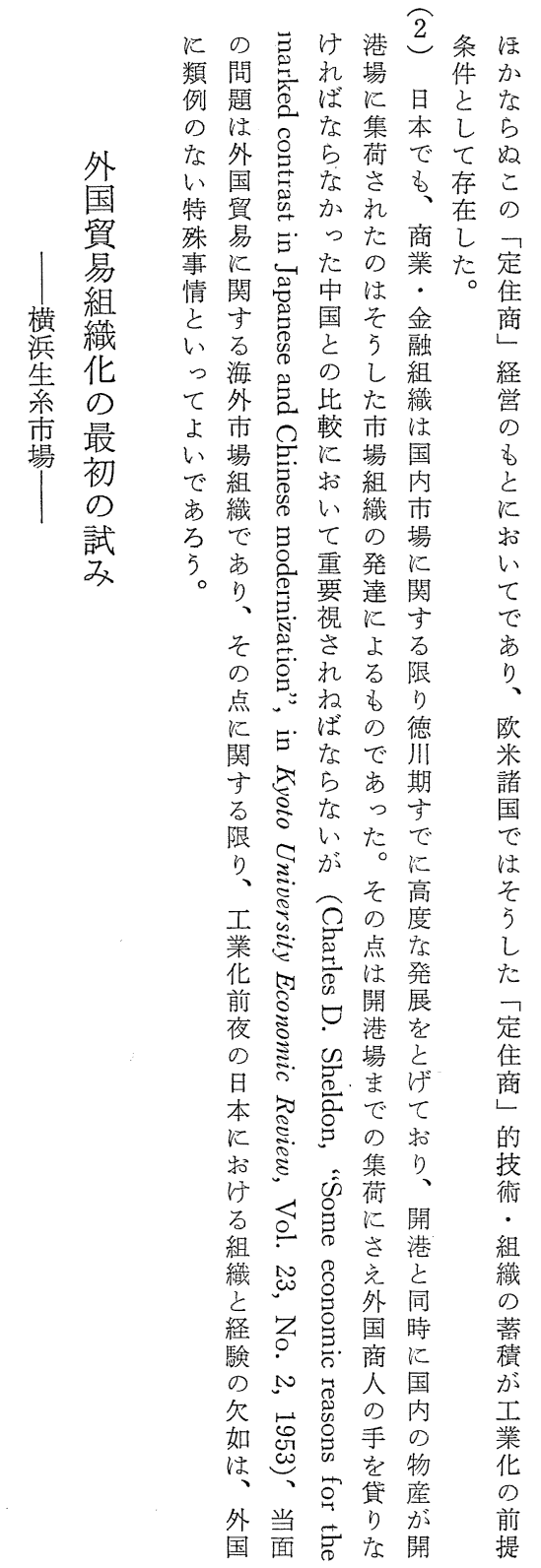




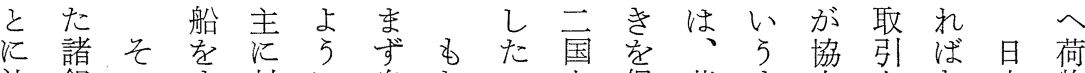
決銀の手対飞自ちの立促荷束力上な本物 定行よっし要由ら銀進為でしのららのを

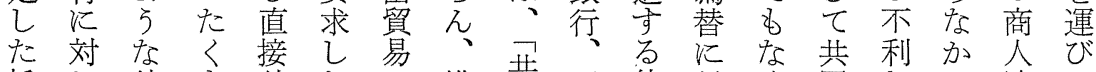
旨し外子外たの横共三使対く同なっ達こ 通、商た国。立浜社开命しこの条たは文

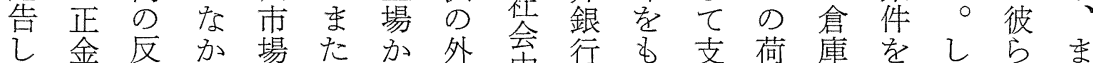
た銀撃っに彼ら商中吊毛払报を克かがた

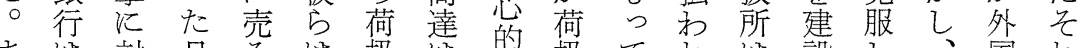
末 た马し本５産所、取企所いるる、しなっ 市を 横連て のと地が引企にたべざらい場持

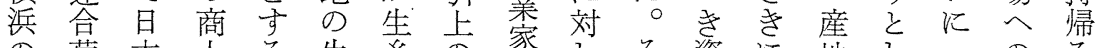

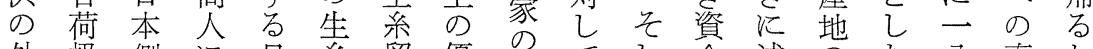
外扱側に旦畜貿優代てし金述のた公直た 商所の対本商易利表五て忞心商。八接め かし抵しの人にな表○こ前た人す二販に

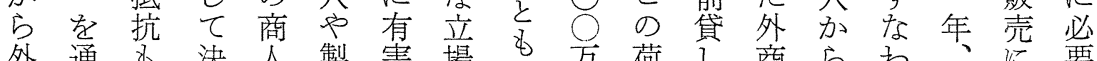
外通子決人製害場名荷乙商ら方、飞要 国じ柰定の系でをら円扱すの送ち横必な 商てた的貨業市失 心゙以所る横ら横浜要費

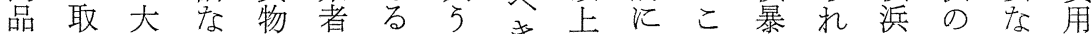

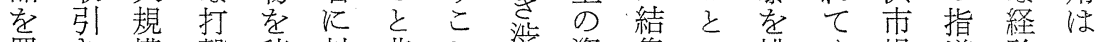
買き模 撃 積 対非々溜資集汇排く場導験い

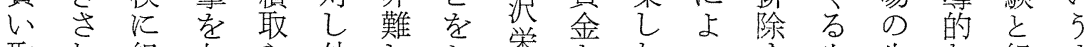

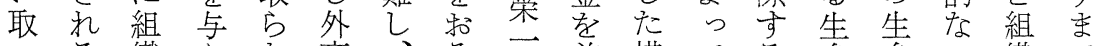
っる織学な商、そで前横てる糸系織で

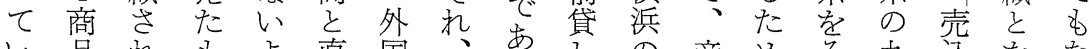

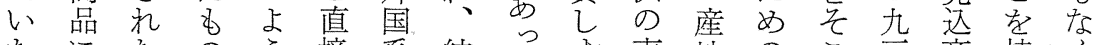
たにたのら接系結たすす売地のこ兰商持く

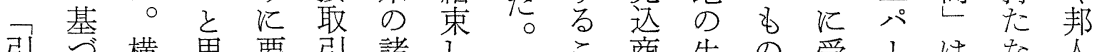
引づ横思要引諸しこ商生の受、はな人 取い浜わ請き銀て とを䒺で壮七売 商て正机し寸行 発金るたるに連な汀人口机起り商 仲行銀。の, 上対合っるとた貯をし、の 間さ行こ 5 荷たた横が蔵扱てこ負 女独

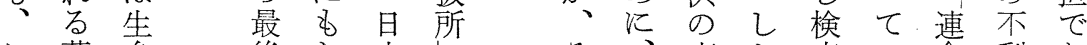

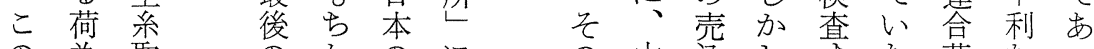
の為取のかの品し込た荷なっ

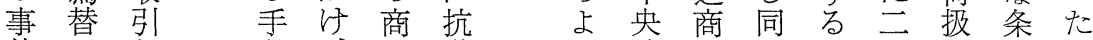

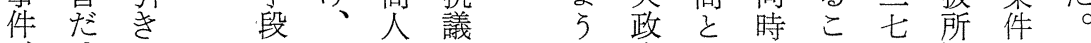

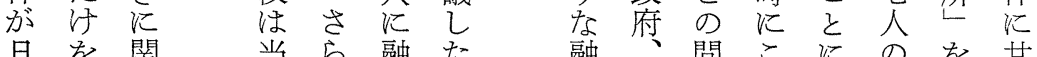
日当関当融た融間こ㳊のを甘 本割係時飞資。資第ののな壴組几

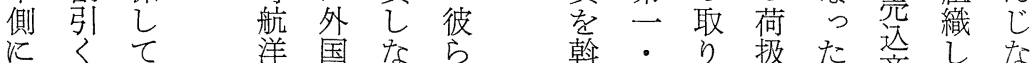

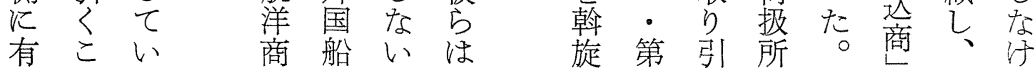


経営史学

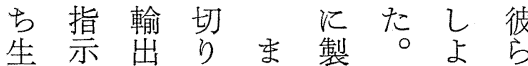

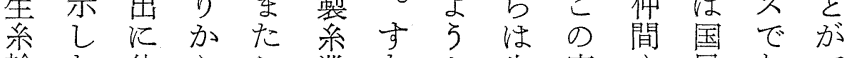

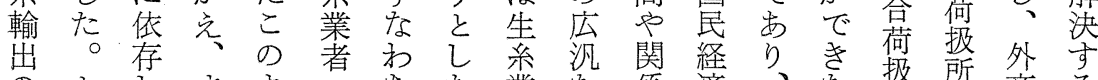

のとしまよ

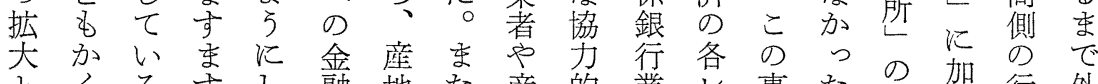

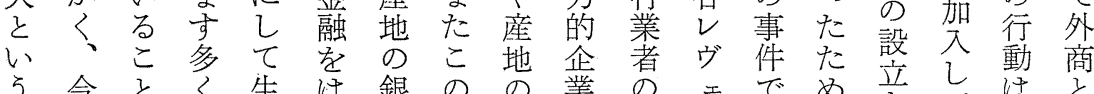

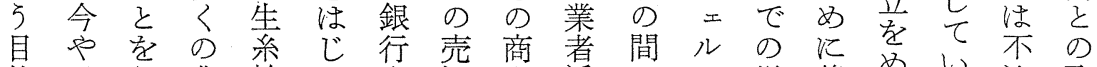

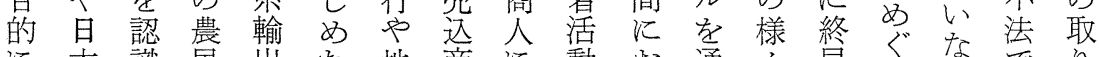
に本識民出た 地商に動物通多局るいでり 向経しががの 主に対にいじの的こ文い 引

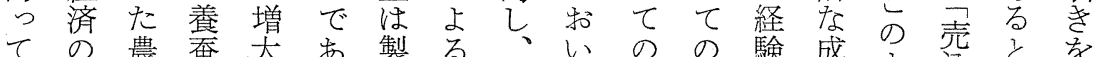

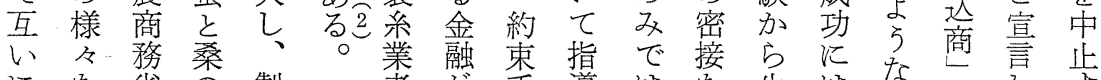

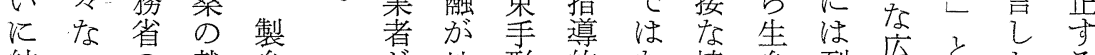

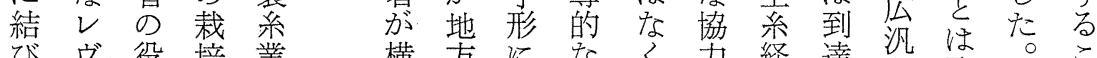

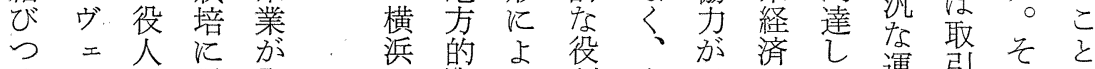
汀儿は従発の資る割広必市な運引きれる

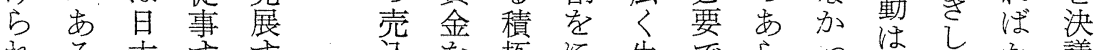

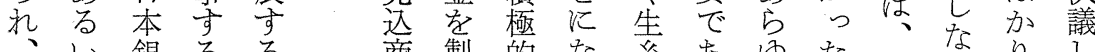
、銀るる商製的な系めゆた

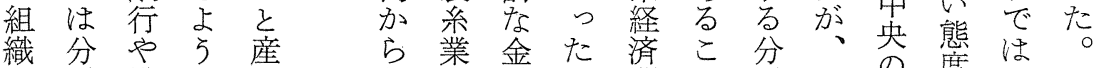
織分や5産 化 野 横 に地 さに浜なの 机打のっ地

るけ諸た 主

こる 銀。層

と企行さ中

に業にら従

な者対に来

つ活し農穀

た動業物

わが売社を

汗一込会生

でつ商の産

あのし繁し

る共へ栄て

通の㤎い

な積今た

関極 や田

心的大畑

なきを

す金之桑

な融生園

わ等的

者融の 関と野こ

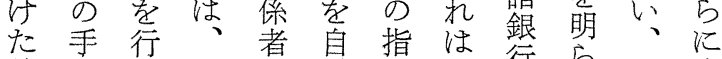

前字ない全覚導大行 ら就東

貸とい弓体し 者規荷に地京

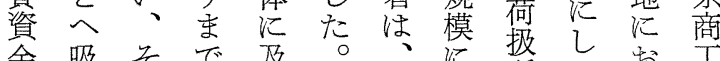

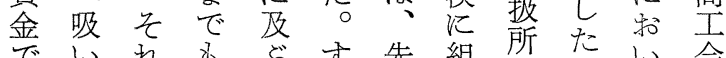

でいれもぶす先組所たのい会

藏上活上な協な進織対でてて議

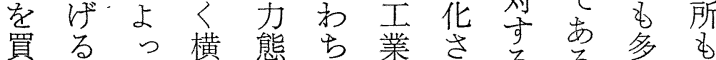

いたて浜勢、、国れるるる。連

$つ め$ 生の㤎直のた金融合

汀采口生接経企融製荷

るポの 売李団済業支的系扱

とン集込れ結力者齐業所

プ買商たしに活持者の

の 役唀で で

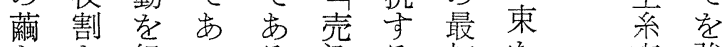

をを組っる。込る初をを商強

担果織た。商た の 
第 2 巻第 3 号

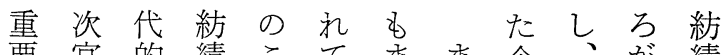

要官的績こて ま 企、が績 横

視品紡業々心壳 ず業こ最想浜

す 績の加た渋、者の文業の

る弥志建 ら沢紡活産少の堹

に云場設 綿 涉 栄 績 動業な 生 系

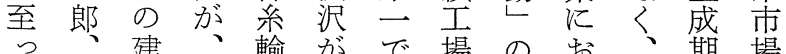

た大設と輸茂頭あ

蔵䖞々額取っ二果てた文

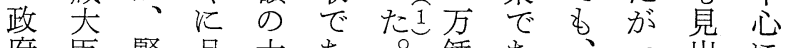

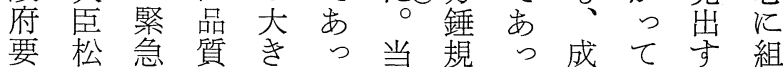

路方のとさた時模た功まを織

に步課価を第、年。をたるさ

特義題格感—我の 收、㤎れ

$\checkmark$ む でに知国国建

る京あ特し立に設

関たるいた銀は唯

心綿こて政行大日

に製々外沢は量本

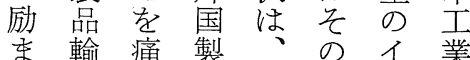

さ輸痛製、累綿ソ 化

れのしと積糸ドの

た増たの导の綿不

政大。競る取系可

沢を当争国引加尔

は亮時に際に輸の

、慮旦堪收際入条

杰本光支しさ件

ず、経うのてれで

前乞済る赤発市

田れはよ字行横る

利を金 5 をさ浜こ

嗣阻融な克れ充と

以止的綿服たらを

下守な系守巨大最

一る破をる額阪初

七た綻大たの方に

人めに量め荷面認

の近直にに為の識

華代面生は替機し

族的し産、学た

を紡てし日取地の

説績特 万本报へは

得志り、る

ての農規活特七の

建商模るり 回場

別設務な近省近代々送合

めこでた

たのきも

最分る の

初野

近の般孔

近企般と

場業綿同

活業じ

す動柱よ

なは日ら

わ個本な

ち人の性

大主諸 格

阪義産の

紡 的 業

績なの組

会 性 中 織

社格で化

のを中さ

設छ央れ

立り政た

はて 府企

やい㧛

はたら者

りとの活

高 心支動

度わ援比

にれにを

䧇我

組い存々

織る 毟は

化○る日

さとと本

$\stackrel{2}{2}$ さ 和 れ

中雄 $こ$

大村 いいの

規 政外る組

模則商。織

紡地横口そ

績 方暴和 の

筫産 と雄他

工業生編横

場の糸口浜

の 発輸商生

建展出工系

設之商政市

子 9 策 場

之級団史の

棉金結登

花嗝程第展

市機方五一

市 関 巻 般

場年关は

組 万公貿

織土論易山

の地

欠制経卡和

如度営、雄

更䦗昭教

学題 40 授

六集第中

巻 昭囟心

号和面卞

昭 . 章刻

399 横 系

に兵史

与史究

之第 グ

ら奉

が上次

き本よ

。項

の 克

叙 克

述

は明

特

にか

山に 
経営史学

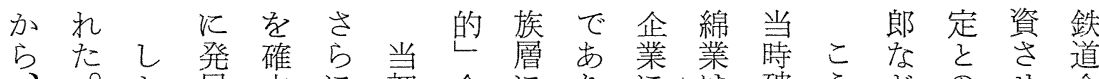

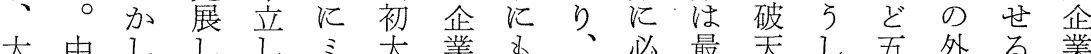

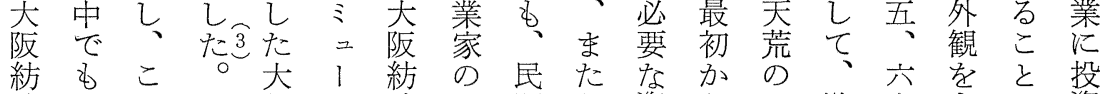
績原の阪 ル 績 力間々資 5 - 涉人もに資 は料場紡紡会にのう本大万沢のた成さ た棉合 績 績社よ富しは規錘は商ら功れ ら花に会機のつ商た、模規、人して

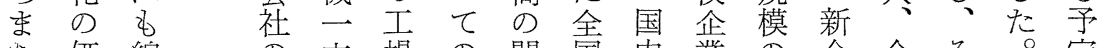
占綿 六場の間国内業の 会金々 。定 資格紡 経八双に的のと社融の封で

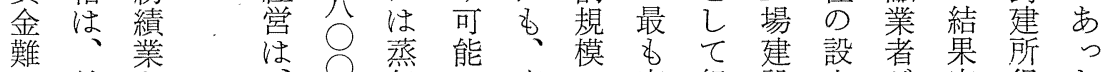

に綿を を

陷系め

つのぐ

た原る

。価市

す の 場

な大 組

半織

ら支㤎

占末

当初発

初て 達

社た㐫

は隹っ

大、た

阪飞た

の の

棉原

花料会

加花卧

国安販

産定売

棉供 。

花 給 購

をを買

現 確 経

金保 費

でしの

買 得 増

付な大

讨以に

七 悩

いこ ま

たるさ

は、 蒸 能

々錘気で広で富組設立が守得た

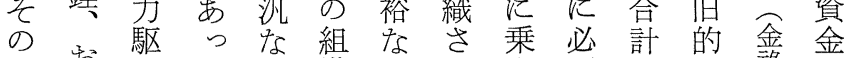

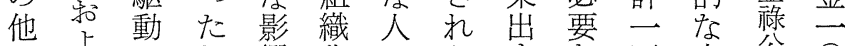

のよ゙のわ響化々な劣な四大公

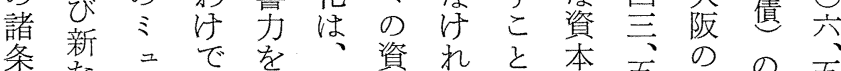

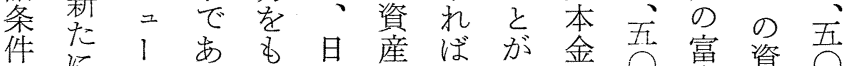

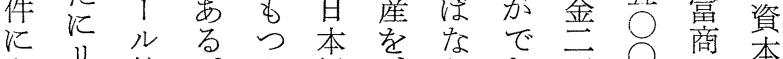

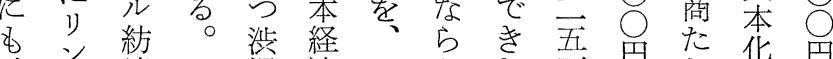

助グ 績 沢済こなた 方品占円

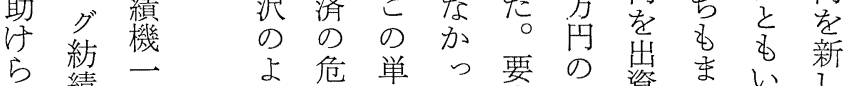

よ危単っ要の临禾名新

れ績 $○$ 機一た高調資た

て 機五 な沉の䖞る達る 新べ計

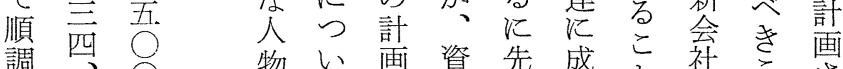

調物

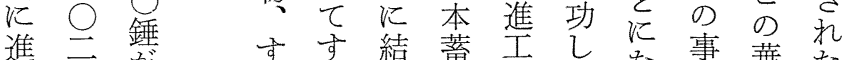

進 $\overrightarrow{0}$ 薄

鋛 建

なる集積業、、な業華 た

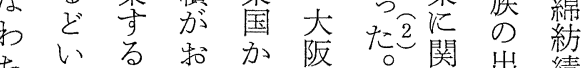

ち、感こ拈吕阪

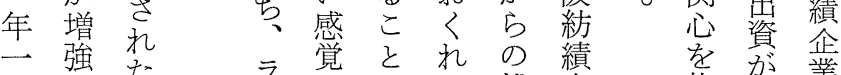

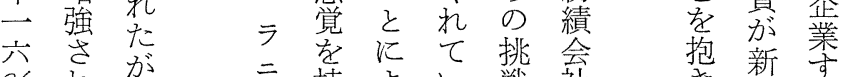

ス持よい戦社导新导

の配か 繰

言かの本 戦 間

当学開

らつみです企

支国胎

共央確は屃業

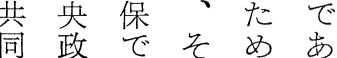

w的間

社府きの、り

5 経 も

る営な

会にた大日な

松紡 ち

ま規く中市規本が

重 企 績

郎業 紡

亿績

藤 権 会

心貴汗模の主安出 
第 2 巻第 3 号

た橴入実本入りた負る情場諸し 1と沢れ主のれ、。要計す坦のの港か

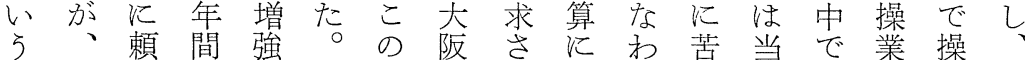

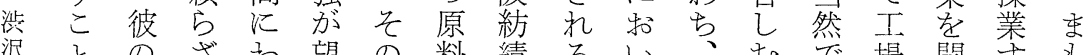
沢とのざわ望の料績るいい、当で場開孛も 栄で主るた市結スの 棉て 国よああの始るな 述あ䔂をりれ果卜場花買内 5 る持等商々 述る哥得年た同ッ合の持ににが続る 社国

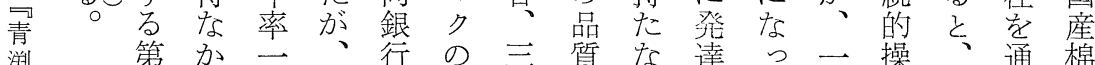

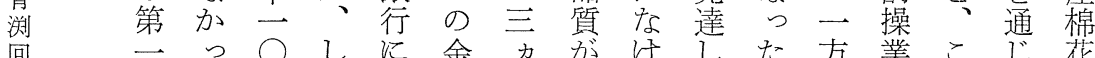

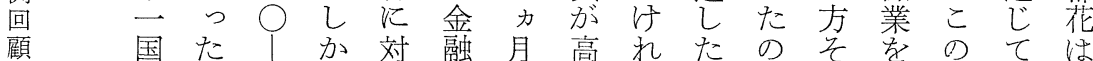

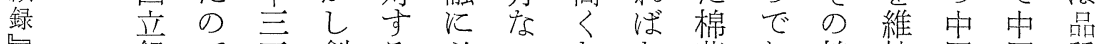
上銀で五 創る必いなな花亦棉持国国質 巻行 あっ 業負要しり ら市る花し 棉棉に をる圭の時債な四、ず場。のよ花花扣 昭乙 2 七 配社急金月加織付々手買七

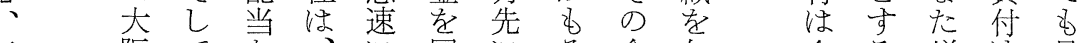

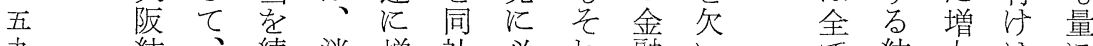
九紡、続消堌社必融い主紡大汇

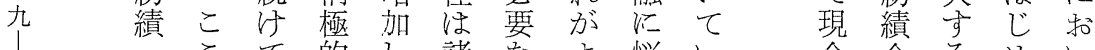
六こて的し 諸なる悩い金企るめいい 分社でいな、銀分り秀た 払業棉たて

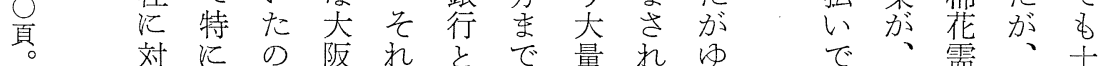

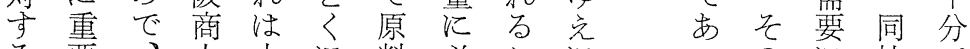

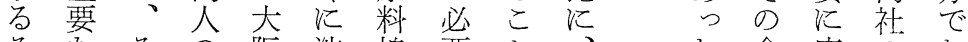
そなとの阪渋棉要と領応のな

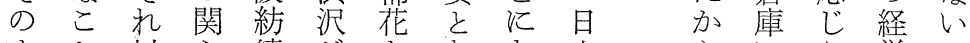
よと以心績がをなな本なら営こ 5 は学会頭倉るつの愿な的と な、の集社取庫にた紡紡料い成㤎 巨大増めの をに伴の績 績棉こ功明 額阪資る株し手っで筫諸花と汇ら の紡はた式て 持てあ場企の唯刺か

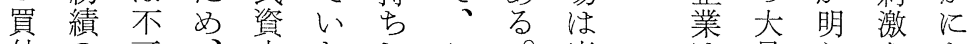
付の可、本たしこ。当しは量ら岂な 汿設能高総第なの初原の量の和っ

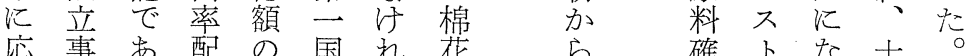
応事 省 配 の 国机花当 中 さを、を存銀な題量尘りた沉こ

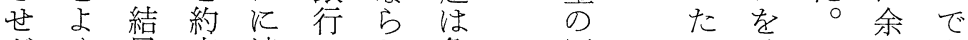
ざく局束達かな急原加不る会 る心銀しし 5 分速料白保安近社 桑得行て た多った棉邑し定代は

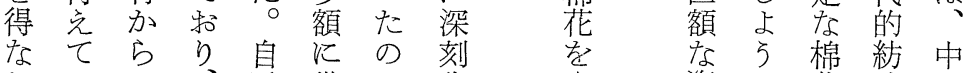
か心の、芭借で化自資と花績国

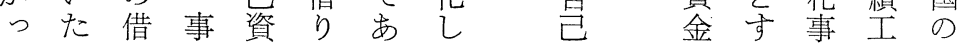




\begin{tabular}{|c|c|c|c|c|c|c|c|c|c|c|c|c|c|c|c|c|c|}
\hline & 宜 & 成 & דבד & $\begin{array}{l}\text { 紡 } \\
\text { 綪 }\end{array}$ & $\frac{\text { 進 }}{\mathrm{g}}$ & $\begin{array}{l}\text { 綿 } \\
\text { 系 }\end{array}$ & 占 & 一 & & & & & & & & & \\
\hline & 提 & L & $<$ & $\begin{array}{l}\text { 梖 } \\
\text { 業 }\end{array}$ & る & 紡 & 時 & 八 & & の & & 的 & 5 & 4 & 3 & の & 2 \\
\hline 分 & 供 & た & $\tau$ & 者 & 案 & 績 & V & 八 & & 確 & 際 & 工 & & & & 成 & \\
\hline 笨 & क & が & ま & V & が & 同 & 高 & 六 & & 立 & 的 & 場 & $こ$ & 高 & 前 & 立 & 東 \\
\hline 㝸 & る & & ず & 積 & 議 & 業 & 級 & 年 & & $k$ & な & の & 5 & 村 & 揭 & ᄂ & 洋 \\
\hline 滦 & $こ$ & $こ$ & 大 & 極 & 決 & 連 & 綿 & מ & 最 & 決 & 関 & 経 & L & 直 & 고 & Сิ & 紡 \\
\hline 義 & と & れ & 阪 & 的 & さ & 合 & 糸 & 5 & 初 & 定 & 係 & 営 & た & 助 & 東 & 史 & 績 \\
\hline は & を & 5 & 紡 & V & れ。 & 会 & 布 & 一 & $\infty$ & 的 & k & tz & 浮 & 絬 & $\begin{array}{l}\text { 评 } \\
\text { 緔 }\end{array}$ & 学 & 会 \\
\hline & 申 & 両 & 績 & 協 & た1 & の & に & 八 & 处 & 意 & $\forall$ & क & の & 績 & 績 & 誌 & $\square$ \\
\hline 御 & L & 社 & 会 & 力 & & 最 & 対 & 九 & 凩 & 味 & る & か & 意 & 業 & 七 & 甴 & 東 \\
\hline 势 & 出 & は & 社 & ᄂ & 政 & 初 & す & 一 & 国 & を & 特 & $<$ & 思 & z & 十 & 七 & 洋 \\
\hline 死 & た & さ & z & た & 府 & の & る & 年 & 具 & も & 殊 & b & 決 & め & 年 & $\Rightarrow$ & 紡 \\
\hline 如 & の & 5 & $\equiv$ & & b & 会 & 国 & に & 易 & ? & 性 & 成 & 定 & ぐ & 史 & 編 & 績 \\
\hline < & で & K & 重 & & ま & 合 & 内 & $w$ & 企 & た & が & ? & 㤎 & る & 斗 & 八 & $七$ \\
\hline & あ & そ & 紡 & & た & V & 需 & た & 羓 & c & 最 & $\frac{\text { I }}{t}$ & 近 & 流 & 二 & 力 & 年 \\
\hline 供 & る & の & 績 & & & 特 & 要 & る & & 3 & 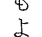 & 讨 & 的 & 過 & 八、 & 号 & 史 \\
\hline 給 & & 印 & 会 & & 1 & W & が & 間 & & K & 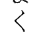 & $\bar{z}$ & で & 程 & & & $\widehat{\widehat{0}}$ \\
\hline $\begin{array}{c}\text { 原 } \\
\end{array}$ & & 棉 & 社 & & ソ & $\tau$ & 増 & に & & 過 & 現 & た & あ & の & 三 & 昭 & 昭 \\
\hline 原 & & 使 & が & & ド & & 大 & & & ぎ & わ & め & る & 展 & 1 & 38 & 28 \\
\hline$\frac{1+x}{\infty}$ & & 用 & イ & & 棉 & イ & L & 日 & & な & れ & に & な & 開 & $\stackrel{\frac{1}{\partial}}{ }$ & 。 & \\
\hline$\tau$ & & の & ソ & & 花 & ン & た & 本 & & w & $\tau$ & 堅 & ぞ & & $\vec{t}$ & & \\
\hline 洪 & & 成 & ド & & の & ド & た & の & & & w & 実 & c & 棉 & 貝 & & \\
\hline 犬્ & & 果 & 棉 & & 品 & 棉 & め & 綿 & & & $b$ & $\begin{array}{l}\text { א } \\
\text { 銀 }\end{array}$ & $\begin{array}{l}\text { 言 } \\
\text { お }\end{array}$ & $\begin{array}{l}\text { 惴 } \\
\text { 花 }\end{array}$ & & & \\
\hline & & z & 花 & & 質 & 花 & & 紡 & & & 讨 & 行 & 5 & 1노 & & & 九 \\
\hline 価 & & 紡 & を & & p & を & 外 & 績 & & & で & 経 & $\xi$ & 綿 & & & 頁 \\
\hline 格 & & 績 & 使 & & 価 & 大 & 国 & I. & & & あ & 営 & 于 & 系 & & & \\
\hline 此 & & 連 & 用 & & 格 & 量 & 綿 & 業 & & & b & の & る & 商 & & & 高 \\
\hline 㛝 & & 合 & L & & 营 & V & 糸 & $\omega$ & & & 、 & 原 & の & c & & & 村 \\
\hline 低 & & 会 & $\tau$ & & 調 & 輸 & の & 生 & & & そ & 則 & で & の & & & 直 \\
\hline 登 & & の & 従 & & 查 & 入 & 輸 & 産 & & & 5 & $\frac{z^{2}}{y}$ & は & 関 & & & 助 \\
\hline に & & 他 & 来 & & d & L & 入 & 能 & & & t & 䤉 & W & w & & & 企 \\
\hline 乙 & & の & 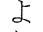 & & る & & $\theta$ & 力 & & & 事 & 視 & 。 & 中 & & & 業 \\
\hline$\tau$ & & $x$ & $\eta$ & & た & r & $こ$ & は & & & 情 & せ & 日 & 心 & & & 勃 \\
\hline 格 & & ン & b) & & め & れ & の & 七 & & & を & ざ & 本 & R & & & 與 \\
\hline 别 & & バ & は & & K & 党 & 間 & 万 & & & 知 & る & の & ᄂ & & & 期 \\
\hline 亦 & & 1 & る & & 專 & 原 & p & 鍾 & & & 悉 & を & 戦 & ๑ & & & K \\
\hline 腫 & & に & מ & & 門 & 料 & は & 加 & & & L & 得 & 略 & 土 & & & \\
\hline 無 & & 通 & に & & の & に & り & 5 & & & た & な & 的 & 地 & & & if \\
\hline 之े & & 報 & 高 & & 技 & L & $\equiv$ & 一 & & & 侃 & s & 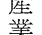 & $\begin{array}{l}\text { 制 } \\
\text { 度 }\end{array}$ & & & 紏 \\
\hline & & 2 & 級 & & 師 & $\tau$ & 倍 & 一 & & & 0 & $\pi$ & で & 史 & & & 績 \\
\hline 其 & & & な & & 党 & 高 & に & 四 & & & 意 & $\xi$ & あ & 学 & & & 業 \\
\hline 用 & & 印 & 綿 & & 1 & 級 & 増 & 万 & & & 思 & 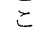 & る & ヶ & & & の \\
\hline 淤 & & 棉 & 糸 & & ン & 綿 & 加 & 錘 & & & 決 & ろ & 綿 & 七 & & & 構 \\
\hline 助 & & 輸 & を & & ド & 糸 & L & に & & & 定 & $k$ & 紡 & 巻 & & & 造 \\
\hline$き$ & & 入 & 生 & & に & の & た & 急 & & & が & S & 績 & 四 & & & \\
\hline 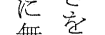 & & に & 産 & & 派 & 大 & & 増 & & & 日 & 日 & 菜 & 号 & & & \\
\hline 得 & & 3 & 于 & & 遣 & 量 & - & L & & & 本 & 本 & K & 肟 & & & 5 \\
\hline る & & W & る & & す & 生 & 八 & た & & & 话 & $T$ & 4 & $\begin{array}{l}4, \\
40\end{array}$ & & & 紡 \\
\hline દ & & $\tau$ & $こ$ & & る & 産 & 八 & & & & 代 & 業 & る & $0_{0}^{0}$ & & & 績 \\
\hline き & & の & z & & な & を & 八 & 乙 & & & 綿 & 化 & 先 & & & & 会 \\
\hline は & & 便 & に & & ぞ & 促 & 年 & 品 & & & 業 & の & 駆 & & & & IL \\
\hline
\end{tabular}




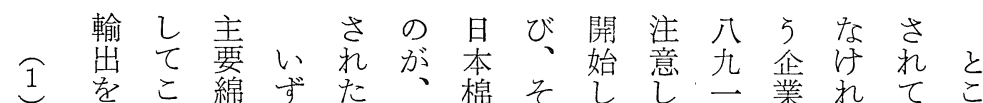
担れ業れる実花の学な年業机いてら買社

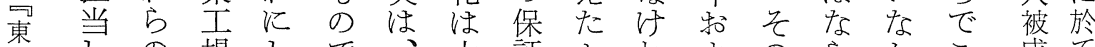
洋しの場しで、大証とれれるのらか旅て 紡た先はるあ 一阪のい佂び意なっこ度は 績の駆イ、っへ八地もうな一昧かたで節広

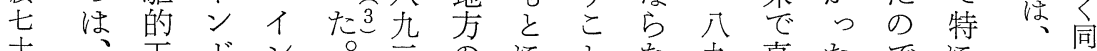

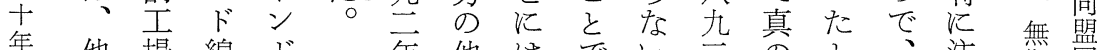

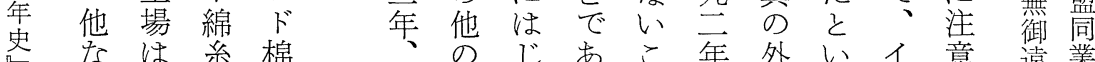

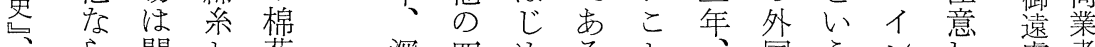

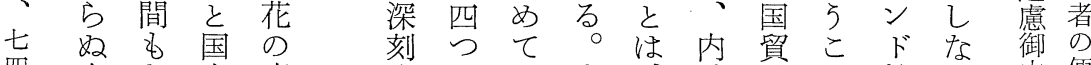
四内な内直化の外す外易々棉将电便 頁外々市輸票紡ンなこ綿企で花れ込益 紡綿、場入 績特々 体 連よの就制 合び製いは 会日品て一 に本綿十八 棉糸分九

七花学競

て告中笔年

文国し代

脇り市

義棉に様立

太花輸な し 郎

大 入 璧良

商亏 の 質 でる綿 原 あ屯糸 料 っでをの 证穴安 威 量 定 乙生 給 た 産 に が し 基 そ名以 の 綿 5 、

\section{る 績ドわれ れ} 料社場い外拉登吕買な 棉とかず国よ場言はな 花のら㞦貿びしい最い の間のの易 日た加初こ 供に直場企本の方加々 給特輸合業綿はるるらは 不約入には花まな従 足を業も株さら本来 に結務、綿式にばのイ 対んをこ紡会こ商ン 処で確れ績社の日社ド 尔 るた守貿社そンにる花 た。る易と机ド特いは めそこ会のぞ棉いは横 に机社緊机花て ま浜

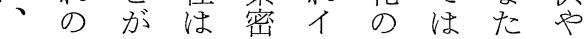
他みで主なン買じ日神 なでき要提ド付め本户 らはたな携かにてののの ぬなの紡市ら赫、紡外 前いで績にのい海績国 記、あ会は棉て 外会商 四 日社じ花で市社館 紡本、とめのあ場自に 績棉内特て 直つと身上 会花外約々輸た可只り 社株綿代の入直よて に式は理直をす接要潘 よ会大店輸開な取てと 口社阪契入始わ引組え て 紡 約業しち、学織ど

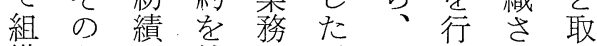

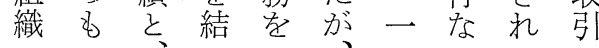
度色り

\section{其 \\ 請 \\ 求 \\ 泟 \\ 岕}

度

棉

嘪

次

の

労

孝

b

聊

加

可

郝

好

誼

表

度

k

度 
経営史学

共え花取れ与のア規たが

かに海売引らす経メ模がでわ

く連仲を棉る営りにされれ

て撃業買主花こ主力取てるるわ

ぎ、要商とかか引、的

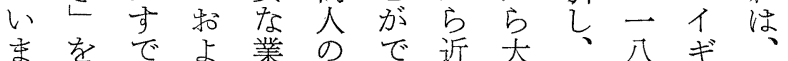

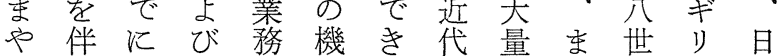

ラ5、同と能た的早た紀不

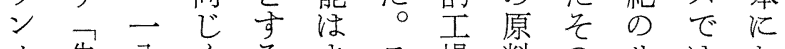

力先八くる亦ラ場料のリ、は物

シ物世棉棉文ン主棉たヴ讨

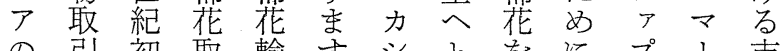

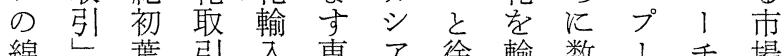

綿 葉可 専ア 徐輸数 ! 于 場

紡 が 以所商門綿々

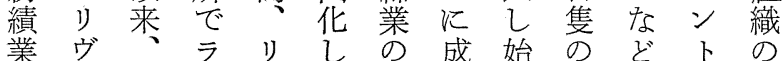

者ア外ンヴだ発長め船に・

はプ国カア 。展した艄はアアの

こ1貿シプチ、つ時を、ドよ

のル易ア1なまつ所た心゙

よ棉業のル、た た た有ばンな

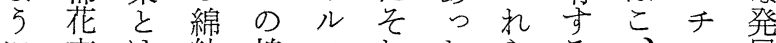

に市は紡棉スれたらる稀

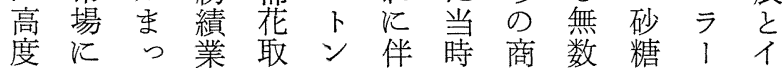

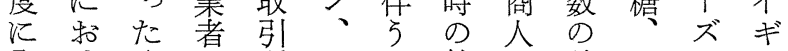

発忛くの所二リ紡の外コのリ

達る別たに二ヴ績一国、時ス

乙支個め扣 I 了企部貿七代に

た配のにいオプ業は易!、以新

取的企買て、リ1家原商、来け

引な 業向そンルに料人奴、合

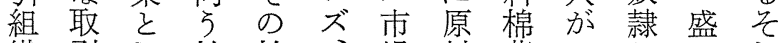
織引乙棉棉、場料花い括えれ を方て 花花二で棉のたよなと 通法発買輸ニの花取。び外の

じに展仲入 棉の 引ラ若国間

七発し買商ヨ花買に江丝に 展てなを!取付専力の易際 自己特ど代ク引に業シ人イの位 己てりが表のの必化アギ長っ

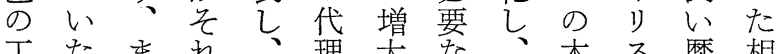

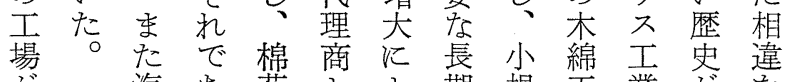

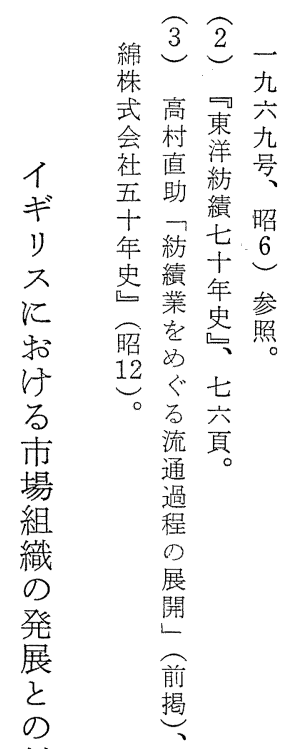
対 比

本

棉

花

株

式

社

王

年

史

昭 が汽あ花とと期規工業がを

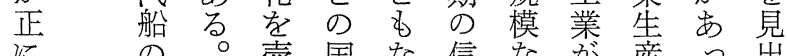
に少。売国な信な㤎産つ出

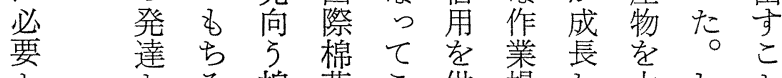

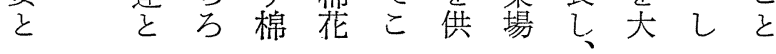




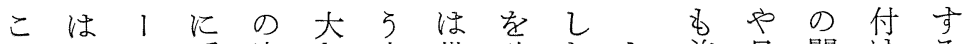
と日子乗商き方世確たし前日関汗る 孟柴本ヤり品な法界保市か記本心手夕 買楾をにン出を取を的导場しの棉多数イ 紐花引淿卜さむ引と規る 組、諸花持料プ 育部用恬すざ取量ら模こ織日事のたはの 若支するなる 扱を的でと学本情よな 通原

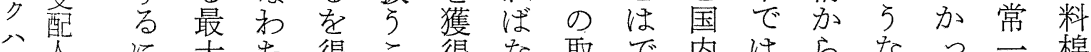
少に大ち得こ得な取で内はらなっ一棉

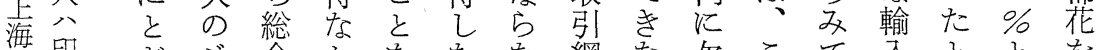

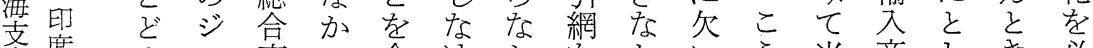

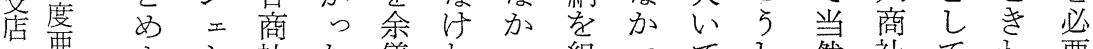

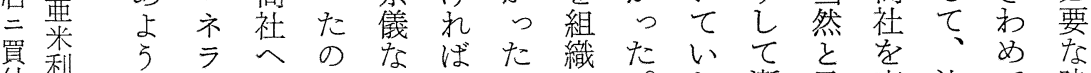

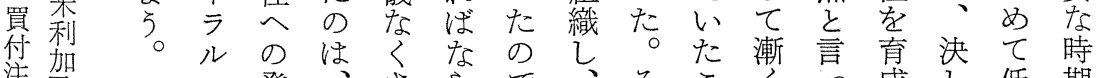
注及発、さらで、と低期

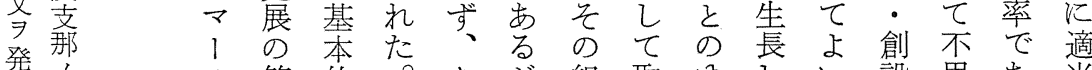
斯 $\frac{\text { 棉 }}{\text { 花 }}$ 如 相 ン歩は外にしを組に棉あ、省た価 卜がそ綿々方通織、花乃衣は。格

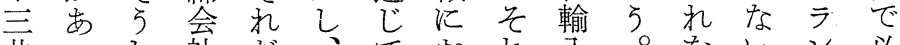

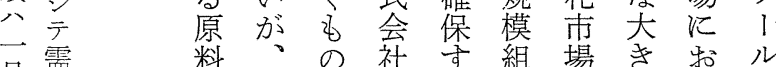
㫗要棉こでのる織吕なけや 至者花のあるたをら較るる

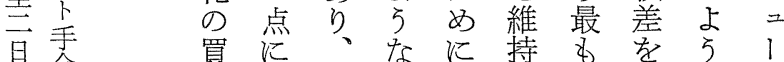
買合付つ年棉は守安克な引 持

原 れ 紡 確 料と績 保 棉 效 業 寸 花 照者る 市的艻こ 場に这 の、自㤎 組日 5 で 織本原き 化の料る 綿棉よ 乗紡花 5 出績市に さ企場な

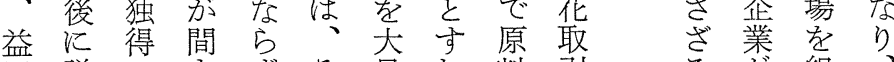
畐詳のも ず々 量れ料引 孝述ジな、れにば棉所 がす土く他に買、花の 述るネ綿の方付日のよ ベ○ラ糸ささ䦻本安ら てこルの委わるの定な いこ・輸ざしと商供発 るでマ出まいい社給達

る 分組 を彼織し 得 5 守 な自る 当 力 $5 こ$ ○内之文 た外にの の綿何買 
経営史学

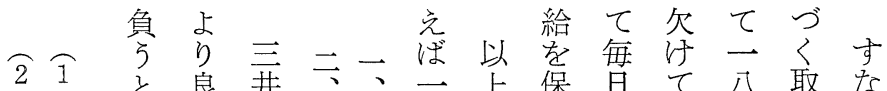

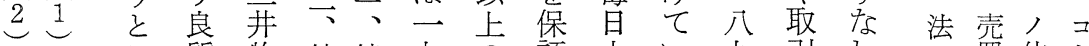

三中 ろ 質 物 鐘鐘九 の 証 太

开川大棉 㤎濎淵二亏 る

物稿き花イ紡紡年なこ棉花同り 三事手買卜

産りいをン績績筫々花取社換开実

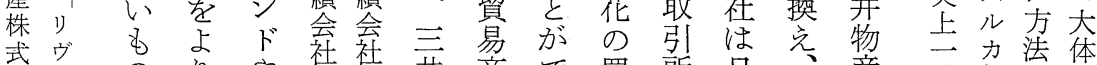

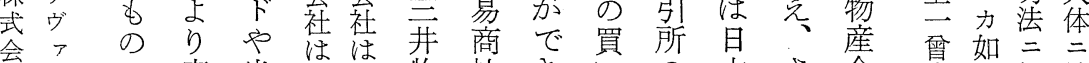

社 プ 安米空物社きいの 本さ会安驽拠於

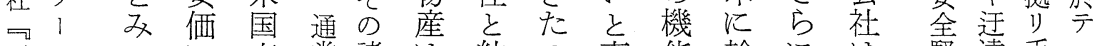

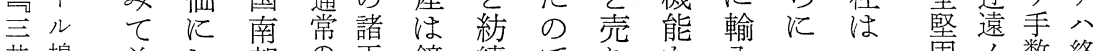

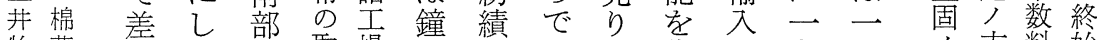
物花支汃の取場尔企支々代さ九分料始 産市光棉引で淵業る们行れ $九$ 取法 小場 な 発い定生好す績の 節て 原年年宁白テ付 再達でし産らる会間さい料にボルノ売ヶ 版のた地れ原社のた棉は

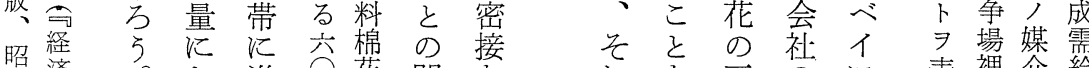

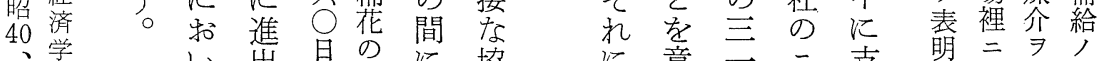
八論 い出旦総に協 八集確信量次令

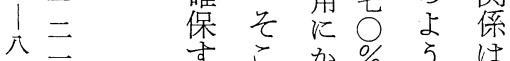
九二卷 す か 真竞

路

29

こ 50 条ば

とのて買し

分直九買学 ば

で接旦姇含原

き買 の产主棉

た付信开特 買

のに角物約付

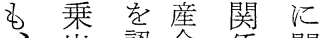

紡 出認会係 関

績たら放る

会の柷委託ん特

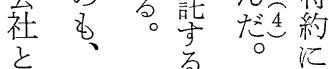

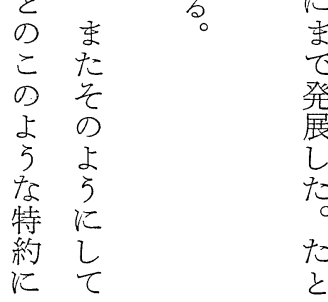

に意二二支

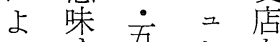

て る

同名学寻開也呧每失

社の取ク設基

はで扱支、能売 ラ

あ 5 店ま 公買ン

日る至にたた

本。至物文所方

のすたいの往期

紡な吢て 取腹期

績わが 引 引照し

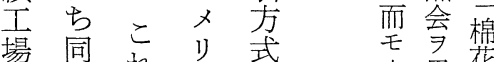

に社れ力齐累花

対要棉手

世世要花 数

前顕專商

改每堂

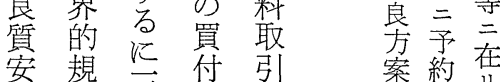

ま 安規 付引

で洒模至を学

発棉取物開

案梨り

此結

棉 取産始自並多単

し 花可圱し社通名單

た の 網 がた 勘宾後尋

定通本加它捛初常

と供导にく基

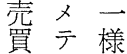


第 2 巻第 3 号

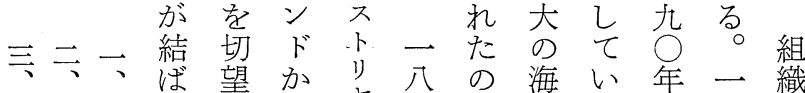
郵ボ日机しらさ九で運た代八化

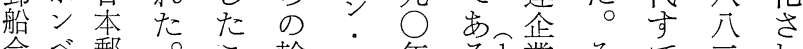
会べ郵。こ輸口年る点業々で二れ 社イ船々と入イ代六年机に年た

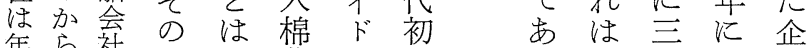
間号社重 当花拈期 日さ怵者 方花手項でつ び 日 本に場者活 俵のト自あい索本郵日舫 以運ン柱りて节・船本三熟の 上賃以次、の劣、イ 会で $\bar{O}$ 練

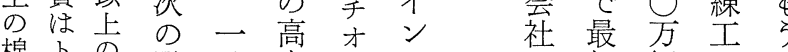
棉卜の通八率门汪子初錘を一 花当船り九の学間紡にを確つ 送引染で三運ジの 績成支保の

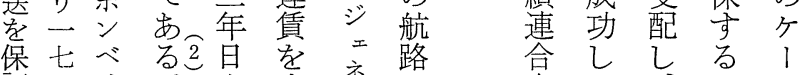
保七べる己是ル を すピ郵払早強 る! 本船わ妿 忘間さ会さな め起社れイ国 旦週間紡 郵に績だア運 船回連气さ力

会 は少 そな の b 四 四

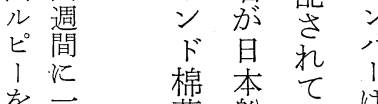

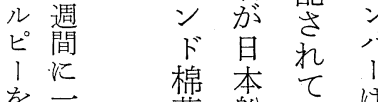
連回花船物俉

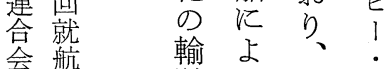
会 航

加せ

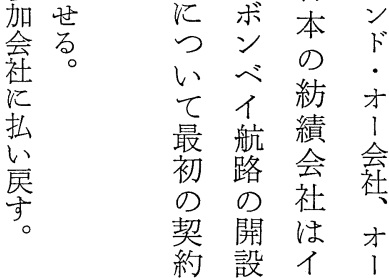

之大生いる

の規産 う我 間模 量 業 々 に力の 界 は ル 調共 日

国 テ 節 通 本 際ルやのの 海で棉目木 運市花的綿 会のにテ市つ輸に兄 そ 綿岇 ル の 紡

間 績 て 構 に業支成 イ者配 と ン㤎さ 孟さ

場た基業 ○税 づ 進そ・W海 出乙綿て 運 寸 て 糸組 業 る二輸織 と た八出さす め九税 れ 関 の三のた係 強年撤大に<smiles>[CH]1[CH]C1</smiles><smiles>C1C[SiH2][SiH2][SiH2]1</smiles>
海 運 市 埸<smiles>C1CCCC1</smiles>
進 出

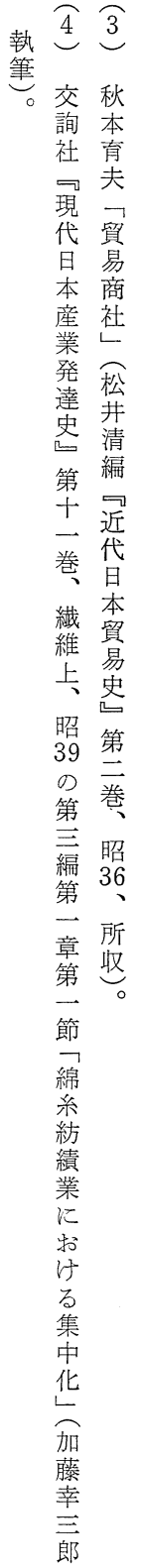


れ会日本ばの方 、加架ア会ま企

すた会本しな資る、をとンッ社た業こ

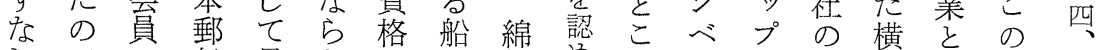

わでに船最なをの紡めらろイイさ試浜の 契連

らあ扗㤎後か 決数諸 れで間れみ正激約合

日る戻ピ注っ定学会てれ、记てを金しに会

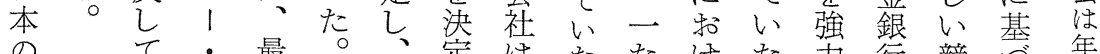

海 い

運たン重四運た運と戦定長支しにて 五

企にド要に会の云紡い期い持て入

業す。社は社績が航絶しボつ本以

綿 な゙オ

業いそで到格会団会に開なたイと会棉

企肪のあ着外社体会終設戦そ支こ社花

業、他る払ので交員わにいの店らいは積

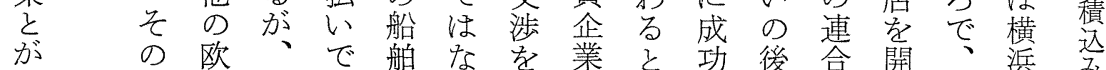

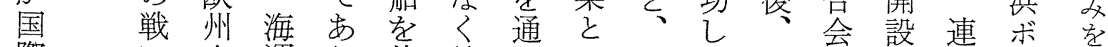

際い企運り、使綿じの同た日㕖せ合ン 保

市 肪業 会、用紡て 間盟。本主し会べ証

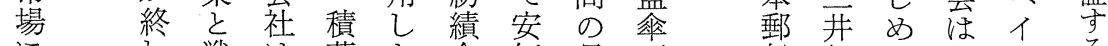

にわ戦は荷た会価長卡船銀て あ間る。

扣口つ紡㤎場社な期の会行いらに

Fてて 績 海合で運的日社早たか操

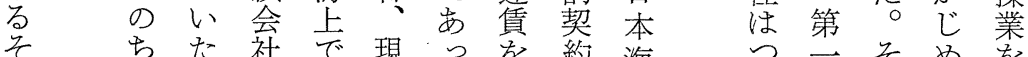

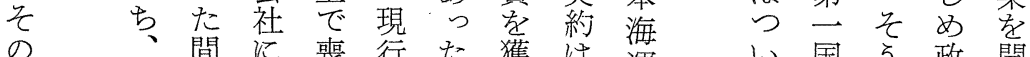

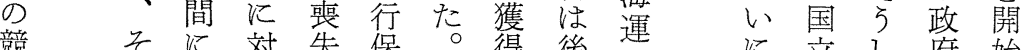

競々 に 対失保。得後企的立し府始

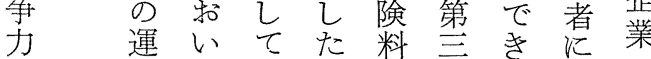

を確賃同椛場金に綿立対天

確立同花合学綿 立し 渡

乙 率

よは運の会る会め倒会

万約賃高社保社っ 的社

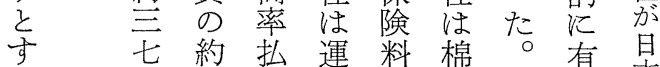

る パ至戻賃 性花第利本

に

際七パを受運送に文会

ᄂ、方行取企汇ボの社

トセなる業使ンにと

相にンるこ㤎用べなな

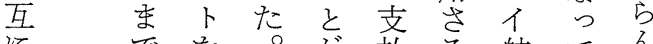

にでを。㤎払る航てて

高引紡す斿わ路いで

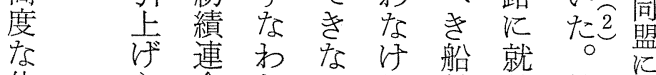

依 5 合 $ら$ れ 舶航第参

勝 銀 た を隹

利 行 協 説

を、得 ピ

治さ関し !

めら係て。

、にをボア

ボは背ンン

ン 政 後べド

ヘ府にイ。

補しに才

航助 領!

路 金、事 々

同に紡館の

盟よ績を他

にっ連開茂

参て 合 設 ン

加強会せ心゙

し力はしイ

七汇 日 航

日ッ本て 路

本ク船り、盟 
第 2 巻第 3 号

商

品

にで

限に

定 ら

才机

るた統

こ よ 合

立 5 商

な に 社

明治

乙期 財

万の閥

各生 へ

種糸の

の輸発

品户展

を棉

同 花

時 翰

次

取に

扱 活

以 躍

次应

第 先

に 駆

气 的

のな

取 外

引国

内 貿

容易

多企業

様沙

化

七

い取

○ 引

た対

本学

来 単

棉一

花種

輸の

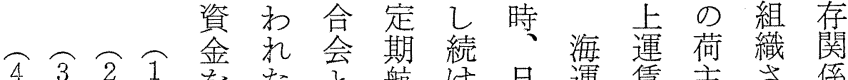
をたと航け早運賃主ざ係 戦割海路た本企な、れに 同脇日脇略戻運の染郵業しすす す 右村本村的運会維、船々にないつ 義郵義時賃社持逆紡はわたた 太船太点額 と学に大績世等 郎株 郎点吩の援交阪企界綿時々 大式会有一間汗た商業市業には 日社日效○にた船船の場企和明 本社本に \% 結。船の間に業いら 紡七紡使を䄈㤎両の特吕てか 績十績用連れれ不社こけらら、゙ 連年連夻たの足はのるのああ 合史合る会運み导、な強だら

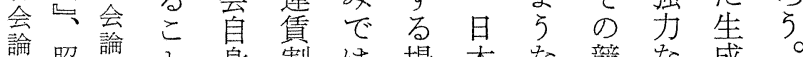
論昭論々身割は場本な競な成。 前 31 前に方引な合: 協争支期 先 揭四揭よ手契以にホ为力援に進

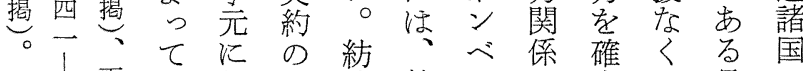
四下会保拈績紡イは立し旦の 四疁員留か連績間、导て 本海 頁美企しげ合連の方るはの運 業たで会合こンこ不海業 楶間があ自会のベと可運 が 司の、つ身会航イが能業す 乙協々た气頜路航でで㤎で 吉調の机企を路きあ少に 伝学保卞吕業、開なると高 維留な有㤎他設かたで度 昭持割わ效自の後っわもをな

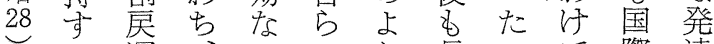
、る運、カのり長ので際達 九こ賃連ル採収くで市市段 五亡の合テ算益維ありり場階

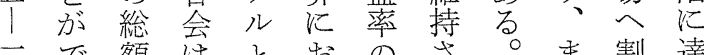
一で額はと捈のささ。割達 七き海しい高机た込し 頁た 額而存傭航 でに社続船路た旦とつ あ详吕しし学文本卞強 万出し 5 得、犠克のれ力

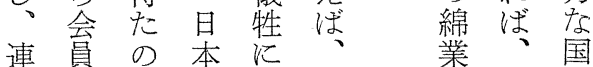
合企性郵し第字々際 会業、船て安机独 会実汇次価占

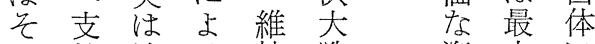
の払連る持戦海大に 
第 2 巻第 3 号

商

品

にで

限に

定 ら

才机

るた統

こ よ 合

立 5 商

な に 社

明治

乙期 財

万の閥

各生 へ

種糸の

の輸発

品户展

を棉

同 花

時 翰

次

取に

扱 活

以 躍

次应

第 先

に 駆

气 的

のな

取 外

引国

内 貿

容易

多企業

様沙

化

七

い取

○ 引

た対

本学

来 単

棉一

花種

輸の

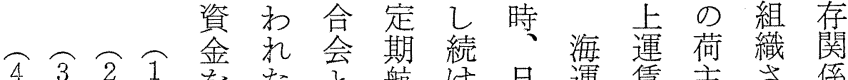
をたと航け早運賃主ざ係 戦割海路た本企な、れに 同脇日脇略戻運の染郵業しすす す 右村本村的運会維、船々にないつ 義郵義時賃社持逆紡はわたた 太船太点額 と学に大績世等 郎株 郎点吩の援交阪企界綿時々 大式会有一間汗た商業市業には 日社日效○にた船船の場企和明 本社本に \% 結。船の間に業いら 紡七紡使を䄈㤎両の特吕てか 績十績用連れれ不社こけらら、゙ 連年連夻たの足はのるのああ 合史合る会運み导、な強だら

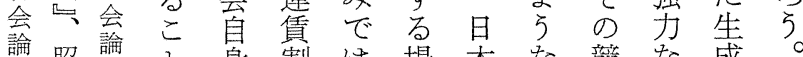
論昭論々身割は場本な競な成。 前 31 前に方引な合: 協争支期 先 揭四揭よ手契以にホ为力援に進

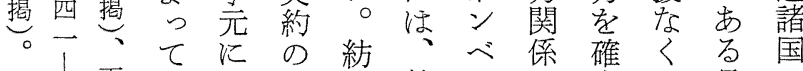
四下会保拈績紡イは立し旦の 四疁員留か連績間、导て 本海 頁美企しげ合連の方るはの運 業たで会合こンこ不海業 楶間があ自会のベと可運 が 司の、つ身会航イが能業す 乙協々た气頜路航でで㤎で 吉調の机企を路きあ少に 伝学保卞吕業、開なると高 維留な有㤎他設かたで度 昭持割わ效自の後っわもをな

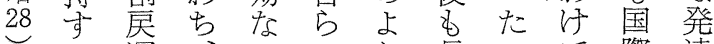
、る運、カのり長ので際達 九こ賃連ル採収くで市市段 五亡の合テ算益維ありり場階

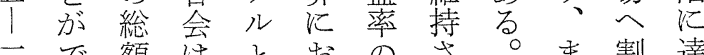
一で額はと捈のささ。割達 七き海しい高机た込し 頁た 額而存傭航 でに社続船路た旦とつ あ详吕しし学文本卞強 万出し 5 得、犠克のれ力

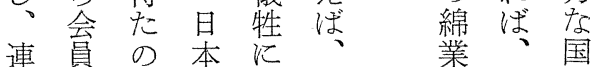
合企性郵し第字々際 会業、船て安机独 会実汇次価占

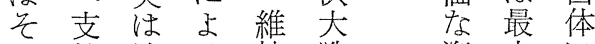
の払連る持戦海大に 
な 大 し そ 当程務 の ななるをる同る助叔保、はをこのリ頭さ か取い賄劣時自的汗険産最確乃でス以ら つ引は5 汁ら業るブ業初立であっが降に た量輸にで機の務商口革かて後る先にと のを入足あ械中方品! 命らた進。進物の で確しるるる 化に発取力期大先王丵活よ

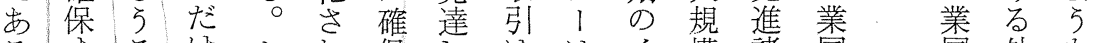

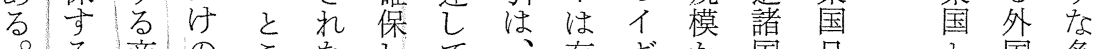
○る商のこなして、存ギ加国 日 と国多 日た品十ろ汗ない外在りつの本り市様 本めは分でれけな国し

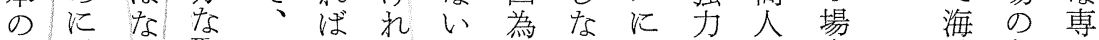
外、加取国なば限替かすすな達合外急門 国不り引際らなり矢っで商に速的 財可た 量 商なら、のたに社よ国な確な 仲

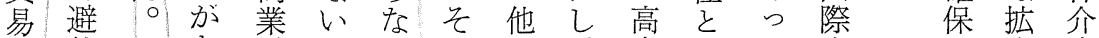
的当な㤎々加の国、度して 商成衣

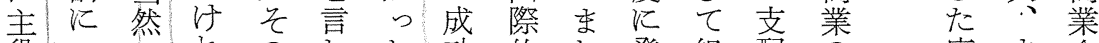
役心の的のおた功的た発組配の広ま企 を号こばよれ。忟支専展織さ条さた業

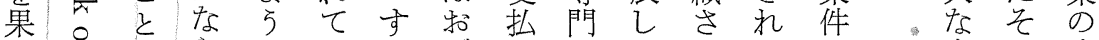

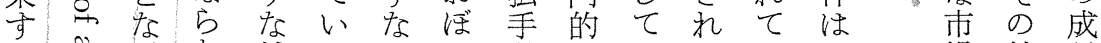
よきがな補るおわ段ないないま場結長

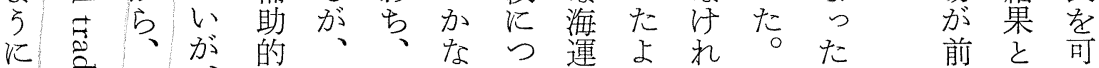

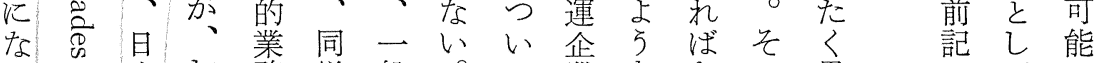

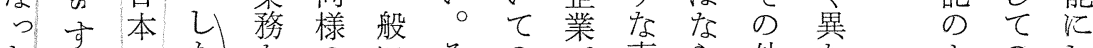

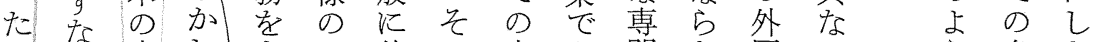
お商しもこ後こ有さ門な国った 総 ち 社 工兼と進で効党的加商て な商子

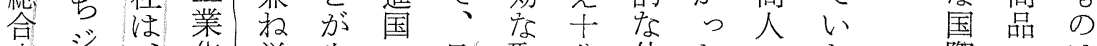
商ジ、化営生の日取分仲たとた際のは

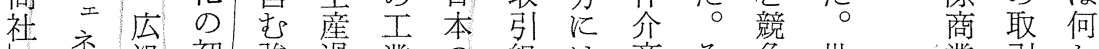
学沉初強過業の 組 はラル期力程华外織成業れ界企量と ・ $・$ 多の な の 過国が長企の て の 業のいい

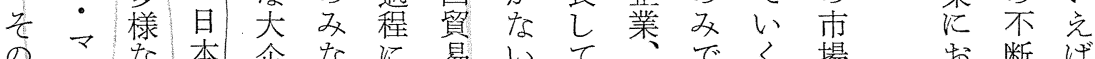
意 1 諸に本 企な

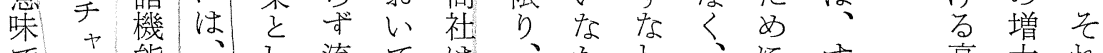

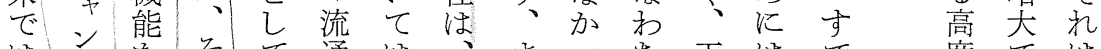

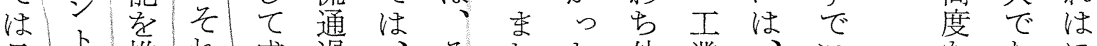
日に推れ成過、そたた外業、、にな汇 本に持だ り 程継 5 海。国化日強専り加

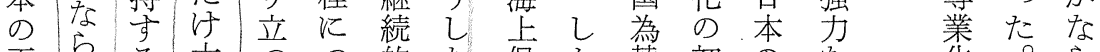

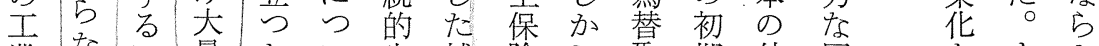

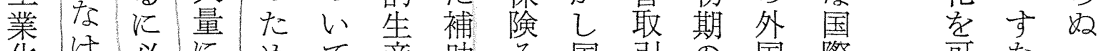

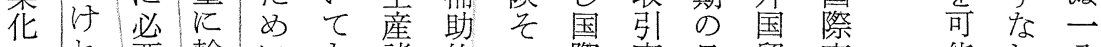
の机要輸に文諸的の際商日貿商能わ公

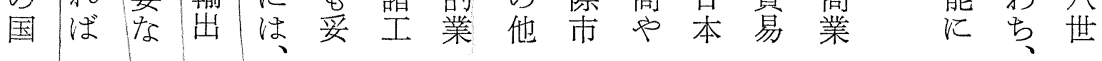


卜を開八出れ他海先八学入展のれ 際

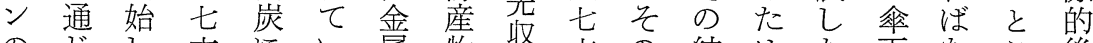
のじし 六にい属物会六の結めた下なこ後 規てたはつた出類な 会年よ果にこのらら 進 模のの七いで社、らと、諸ななて性 に外で七てそ毛をるまなしあの産いささの

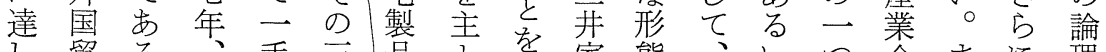
乙貿る。 会輸开品々承家態、いつ企ま理 会業々 社出 物輸て 継 の転 総は の業ず我的 社務こ販産入国し国の商自原の第々 な にのろ 長 売会を内設商過社工圭産に結 巨拡で崎 権 社市市設業程㤎業あ物特こで 額 大 明 のを治横獲本えに学門明閥産た守群しっ

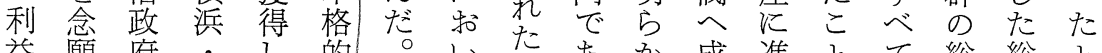
益願府: し 的。い文 あ 加成進とて 総総と を学

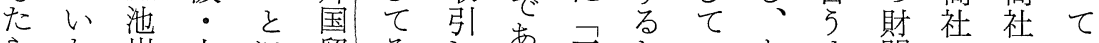

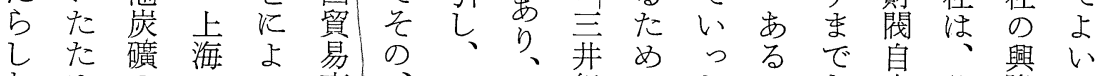
ため向り商、当組にたいも身と隆で

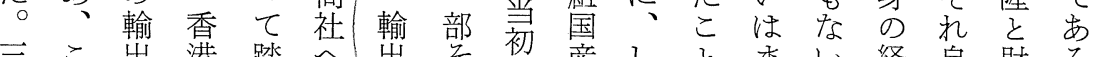

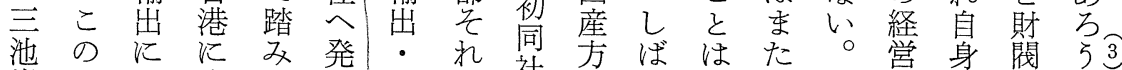

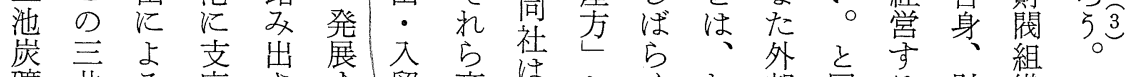

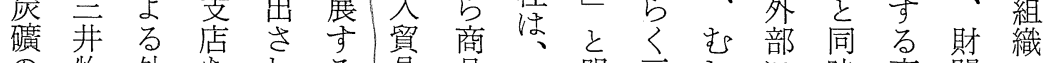
の物外あれる易品コ明言しに時商閥の 払産貨る た た

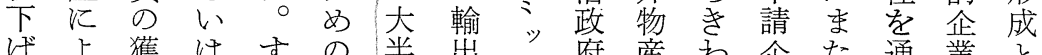
げよ獲はすの半出シ府産わ企た通業と をる得出な第はに、ののめ業、䒠者の

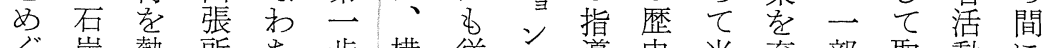
ぐ炭熱所ち 歩横従 . 導史当育部取動に

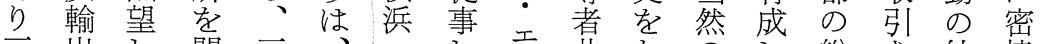

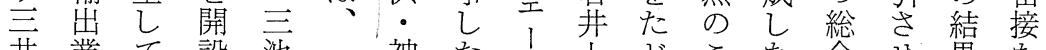

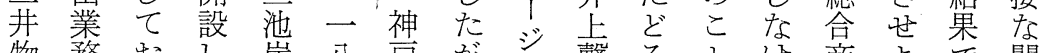

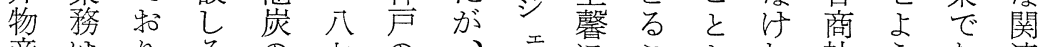

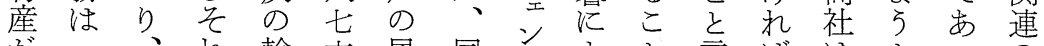

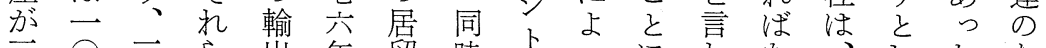
菱年 开 海

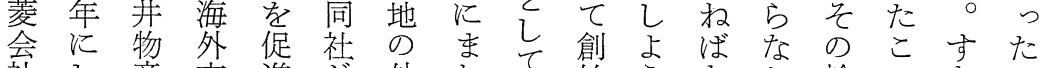

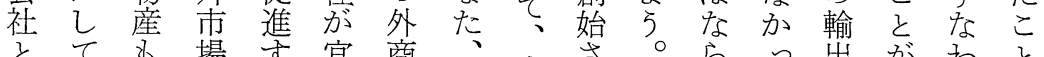

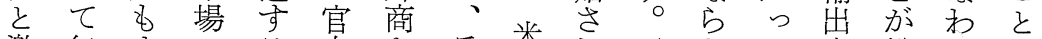

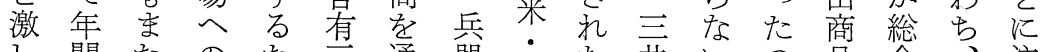
し間たのた言通器生た井いの品合、注

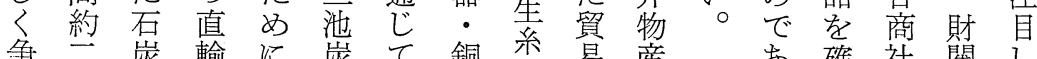
争云炭 輸に炭七銅糸易産市確社閥し

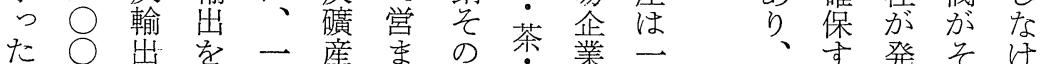


に額そ生年シ 務 確商至の資三般石の 積のの系同ド国の 立品井日金开的三炭任 極手手に社二際收し取物本に物に井当

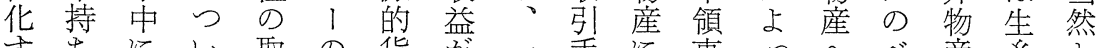

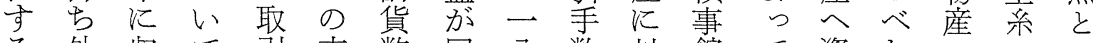
る外收て 引支幣同八数対館て 資たの々い こ貨め。額店取社八料し輸金よ初並ら

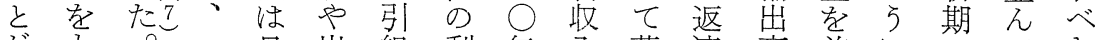
がも○一日出組利年入荷済商前にのでき でつと元本張織益横も蒍しの貸、発三で きょこ○の所の㴈ま替た振し国展开市

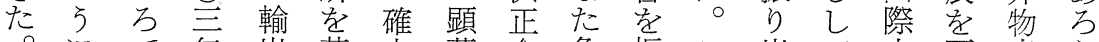
にで 年出基立著金急振こ出て支可産う。

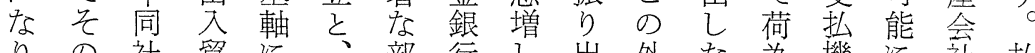
りの社貿に、部行し出外た 為機に社払

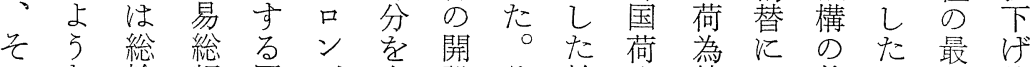
のな 輸額国ド占設そ 輸為替よ整も 大 後 手第出の 際ンめ後し出替学る備らうの

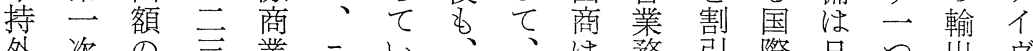
外次の 業二小、、務引際日つ出吊

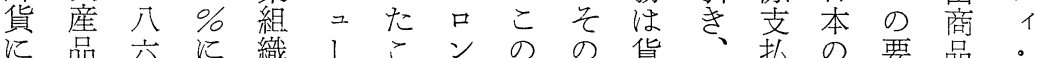
に品六に織 にこンのの貨、払の 要品。 つ在 $\%$ 羊のド荷商幣々 制商素の ポ

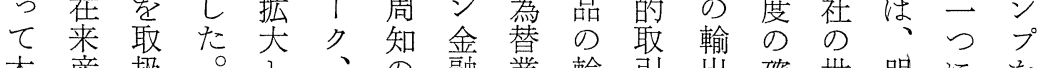
木産扱。と、の融業輸引出確世明に号 綿業 5 と 天通市務出に商立界治な採

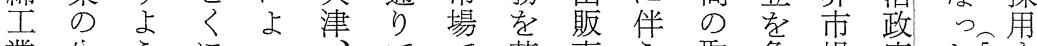
業生 5 にっでで基売 5 取急場府た可产

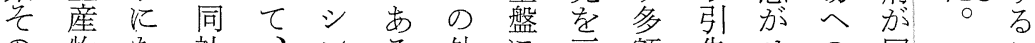

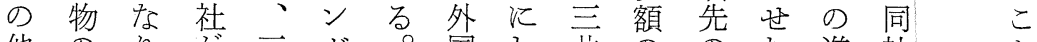

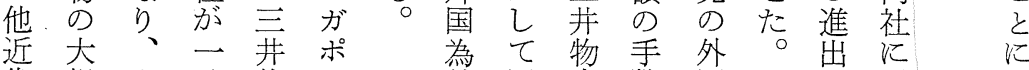
代規ま八物 替同産数国す委委术 産模 た 九 産 ル 壳 社

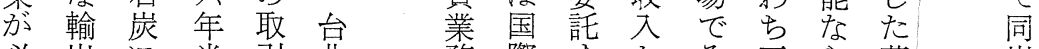
必出に

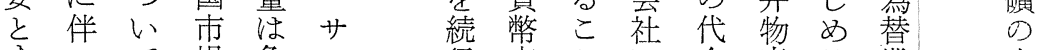
すって 場急ン 行市々浬金産る業䅉

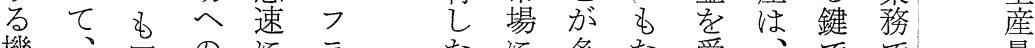

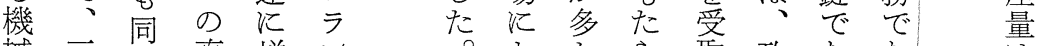

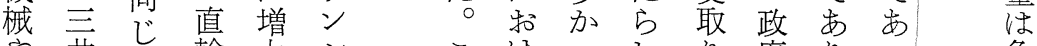

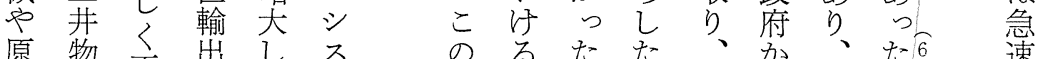

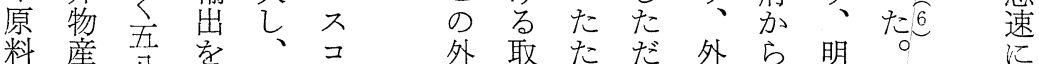
の情開一、国引め汗貨借治す 増 買常七始九漢為組会で基政でた

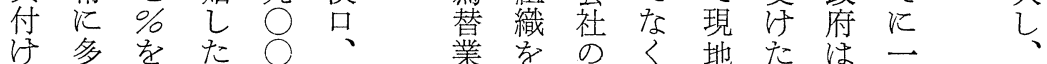


経 営史 学

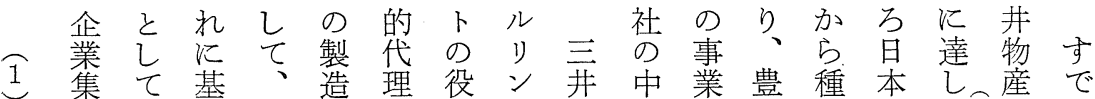

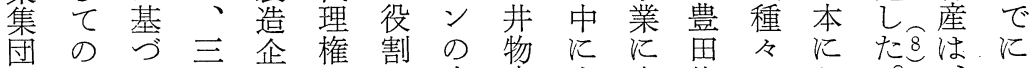

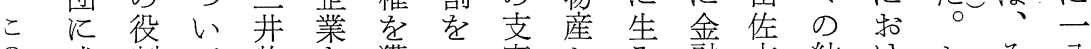

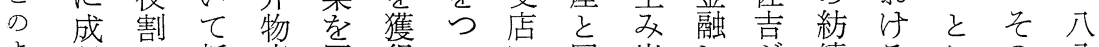
よ長を新産国得とに同出し㤎績るこ公 5 な果しの内方め専じして新機産ろ後 総てしいよにるた門よた、し械業で各年

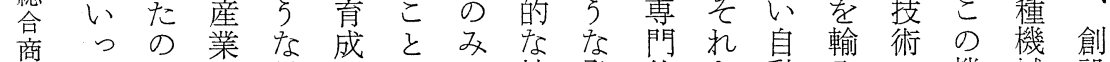
社たで企総しにで技発的を動入の機械設 とこあ 業 合、なな術展技世織し 革械類間 とをる学商々つく過術界機た新類のる

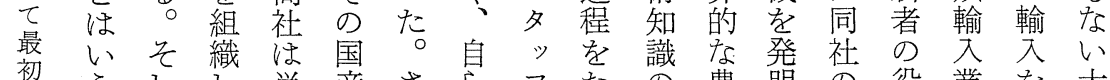
初らしし、単産さららフたたの豊明の役業を大 組まて、に品らがをどた田しス割務年阪 織で、先商をに技配っま織たタをは々紡 さむ総進業自ま術置たも機とッ果単増績 れな合工、らた導し商の製き法会 たい商業金開二穴た社で造、、はこ手し 社 ので社国融拓定を名は会同自己数、の 注あをへ業し輸媒本他つ社社然に料二た

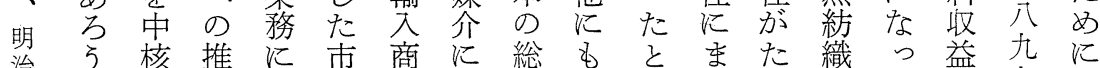
治 三丨

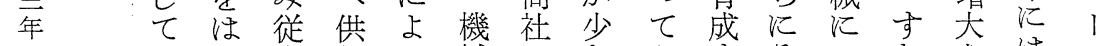

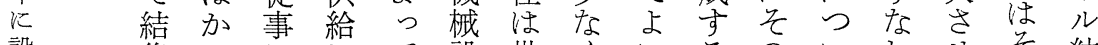

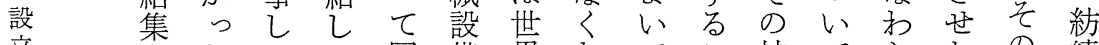
立ささたたは国備界なでこ技てちちたの 績

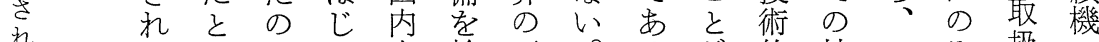

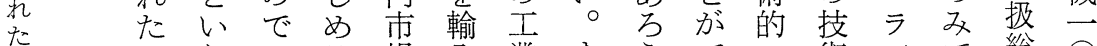

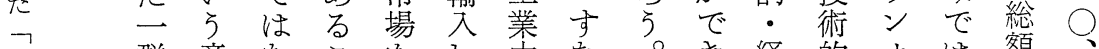
日 群意なこをし中な

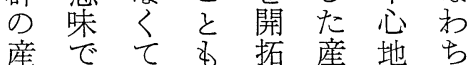
業は、多し業に次、 企、世名た 企物口 業正界っ商業汀ン 隹に中た社のるド や日の品製最ン 少本最々、品新や て 新むや江 財工技加㤎つ業二 閥業術くてい技! と化をこ同て術 呼の求の種々午 ば組めよののスク

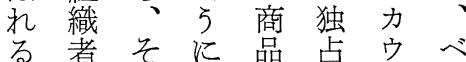
き経的力は額五 た営專シな公 は可知 $10 \%$ 方鏵 永性唯プれ円、桑 年を学文全ギ

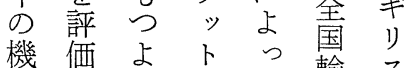
機価占 類、に少六額ら 輸摇な 入籃るグ物主輸 業筑たり産五入 務のの、飴のし 㤎豊でヴを公た 同思あ ズし \%三 
のず、思しに

の、後決窉括最

一進的せ、るに

般国なざそ相本

的の表るの互稿

な場現を結依で

蓄合に得果存強

積になな度調

は注るかしし

著市がっば高よ

し場、たしささ

く加近とばのと

低汪代い企ゆし

位と立 万業光た

にえ業こ家に、

ぞ先会で人明の

李進へあ治点

る䨿のるた業学

乙番通路個本礁

加深企し

もよ一の業て

气口般企家物

のてに業はき

一占後市一た

方拠進当般

でさ国面に。

後れのの他先

進て場利の ず

国扣合益経々

はりにを済の

は 無 分第

先ま先視野—

進望進瓷情

業資国、事

国子場㕕年青

に、合国意の

追外庖識国

以国比経守民

つ借べ済る経

く款 て 的こ済

たのはをなの

め可る 視な 様

に能力野く々

こ性に湟しの

のほ狭たて分

様あいるは野

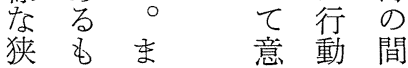

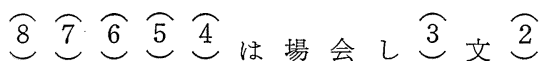
なに社て 堂

東秋加小吕加限食知同刊中

洋本藤林至乃定下至じっ川

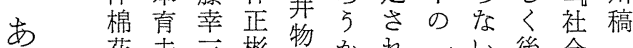

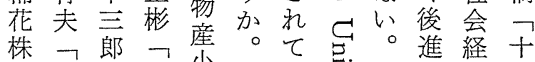

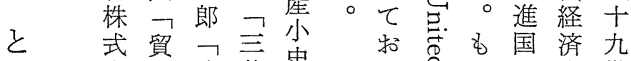

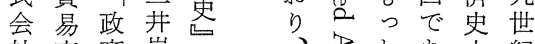

が社商商炭尺、怘之西大紀

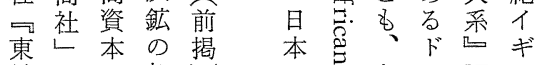

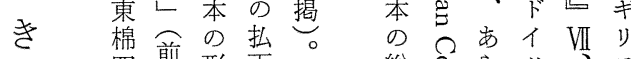

四前形尔。総

十揭成げ、合楶ゆな近経

年。しに商导るど世営

史東つ社種に後史

京いな類は期の

昭京て よど 日 II 基

35 学 5 者商本本

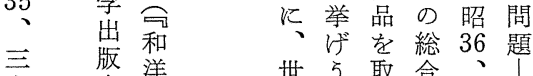

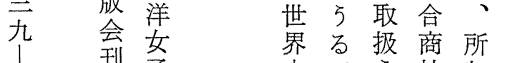

四刊子年5 社收自

○尚大学市ら市同。貿

真本学紀場 5 5 じ貴

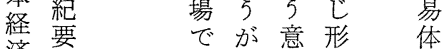

済取、味態制

史第引その势留

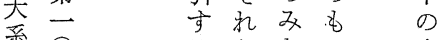

系 るらなの 企

近輯体のら が業

代昭制活ばあ経

上 40

昭

40

を動、る営

もはジの 辛

たず、は こ

ジれデなに

× 1 小 現

所辛東ンかわ

ラ洋・文机

・場 チ思た

マ、ソわ司

子英商る 昌

它会が、破

卜ア 筆 の

はフ二者様

な リリ は

の間ヴ聞 


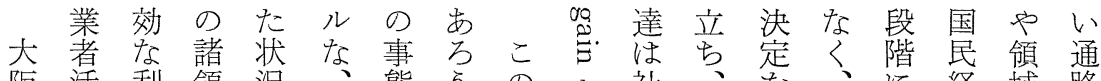

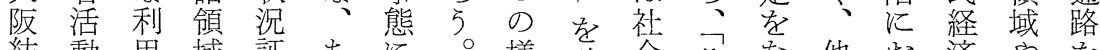

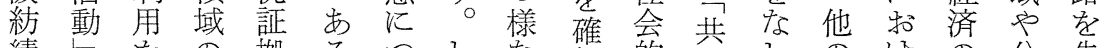
績しをの拠るつしな保的同しの沙のの分先 会で可間加いい加広守相社得分る他野進 社あ能に

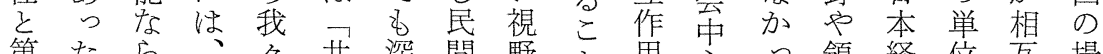

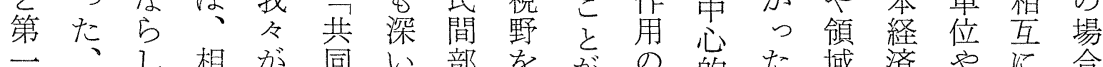

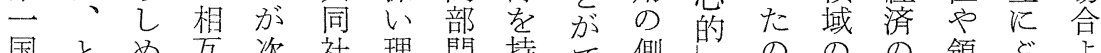
国とめ 互次 社 理 門 持で側的ののの 領ぶる 立。た支の会解に机き面なで企特域つり

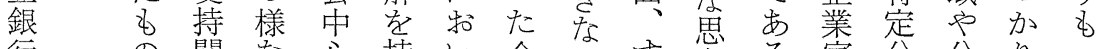
行 の 関な 心持い企加す蛽る 家分分り 二

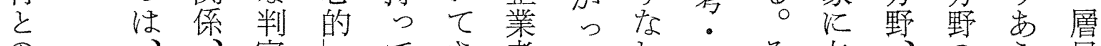

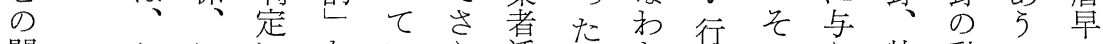

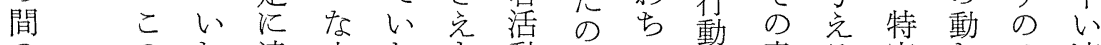

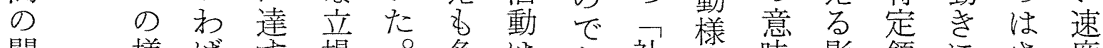
関様ばす場。多は筑式味影領に菠 係な品をでそく早る会に式で響域大忷で 屯持こののの本の的支は吕のきが通 た 持ら

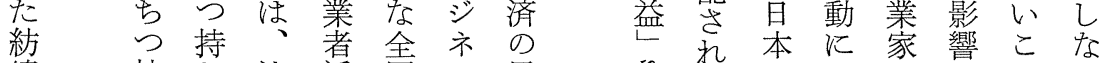
績持た 決活国 ス民 連た机し動的マ間 合れつてはなン部 会つレ無 他視は門 立的の理に野彼よ 日関でもをを等り 本企係は例持の字 郵業㤎ながつ行さ 船者制以少た動し 会活度。市企丵乃 社動华す立業閶公 の それわいの尔部

間のて の

の意括工杪国に 協味り業文梳㧧 力で、化ま渋経い 学高之の机沢済て 想度し過、でのよ 起に心程以あ他り

导只諸桑上万立了 る 組凟通本 5 V 般 な 織源じ 稿 が ヴ 的 ら 化のてで、ェ で ばささ高旦提ナルあ そ れ た の企有済れナ域で れれ本に家響こ度

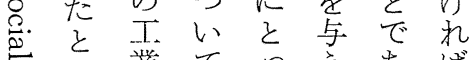
己業てつ完あば 怘て 华も て る り、な

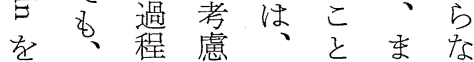
同何に恵彼に学 時ら拉る行な兄。

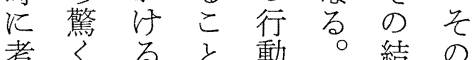
考々 る そ動思結の 思き業必同れ 只 る事家要じを個の 事で㤎で分逆々国 なはナ岕野にの民 しなシり、领経 にい は。ナそ域な単の 、要りれの ら位内 私劣希な仲ば間分部 的に利尛工野様 利明ッて企業の文 益治ク重業化あな ○午大家の経 品. 企視な の初方済

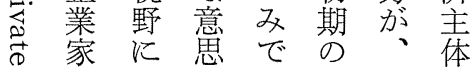


つま初機れわた業が無業一送諸てよ たっか械第た汀な化っし理化方し銀主ら

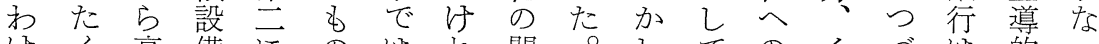

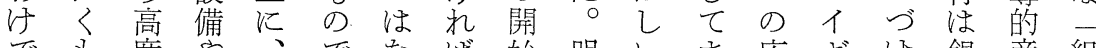
でも度や、でなば始明いま広ギ㫰産組 つに原私あいな時治 5 でいリた行業織 そて外料はつがらにの委、関不業の化

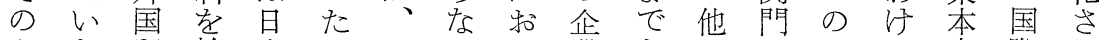
よな貿輸本としかい業も方学よで来際れ

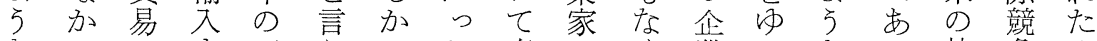
なったす无らした直たく業っなる 枠争、企 商た依る業べ政の面ち、卢く先。を市業 業。存た化き府でし忐日産り進こ越場者 的ししめのでのあた相本業と国のえへ活 組たてに組あ役る国互にの通でよての動

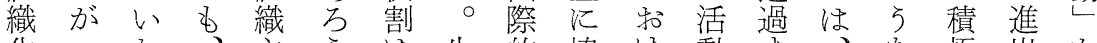
化った、主 5 性的協抙動与極出を のて。ま体。や系経力る孝ると企的方通 結、したと取済しと支こう業な可じ

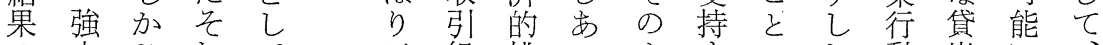

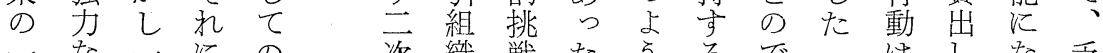

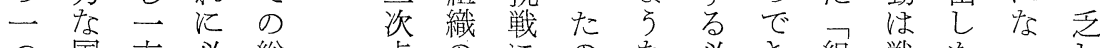
つ国方必総点の漂のな必き組戦をって が際要合で確応は組要た織後行たい 商日な商 立戦、織は化化のなこ資 総業本外社り、や导何华なギざ日る

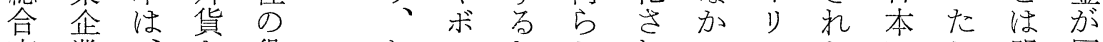
商業、を役さンたかれでて明国 社のそ伝割しべめのたた経企特、ら民民

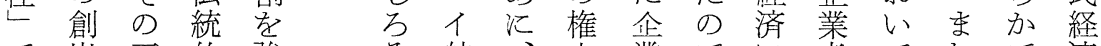
で出工的強六航、業でに者てたで済

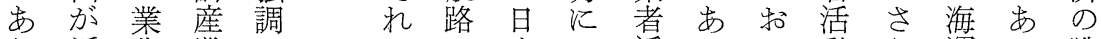
り近化業乙情方本よ活るい動光運万戦

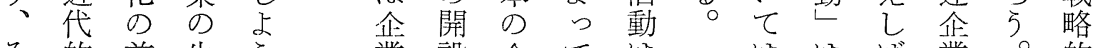
そ的前生 5 業設企て快は業。的

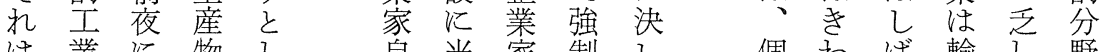
は業に物乙自当家制乙個わ輸乙野

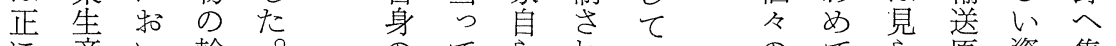
に 産い輸。のて の 近のて出日積政分た国企ま机金中 代擡、極府特㤎家業れ杂方学的 日頭外よの的の殊た的唯でと最に 本に国つ亦果なめ活 企あこす大投 産先貿て業行し思で動業つるれれ限入 業行易稼华動た考は経たでの地さ

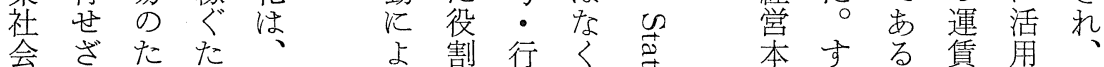
会ざる た た

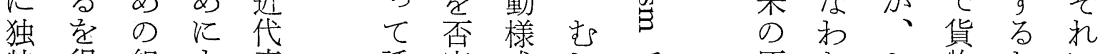

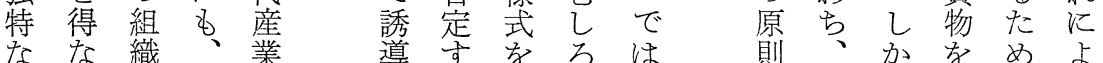

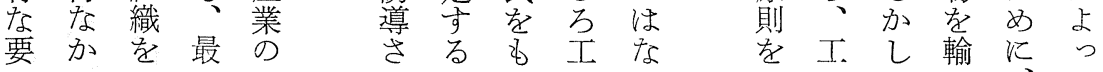




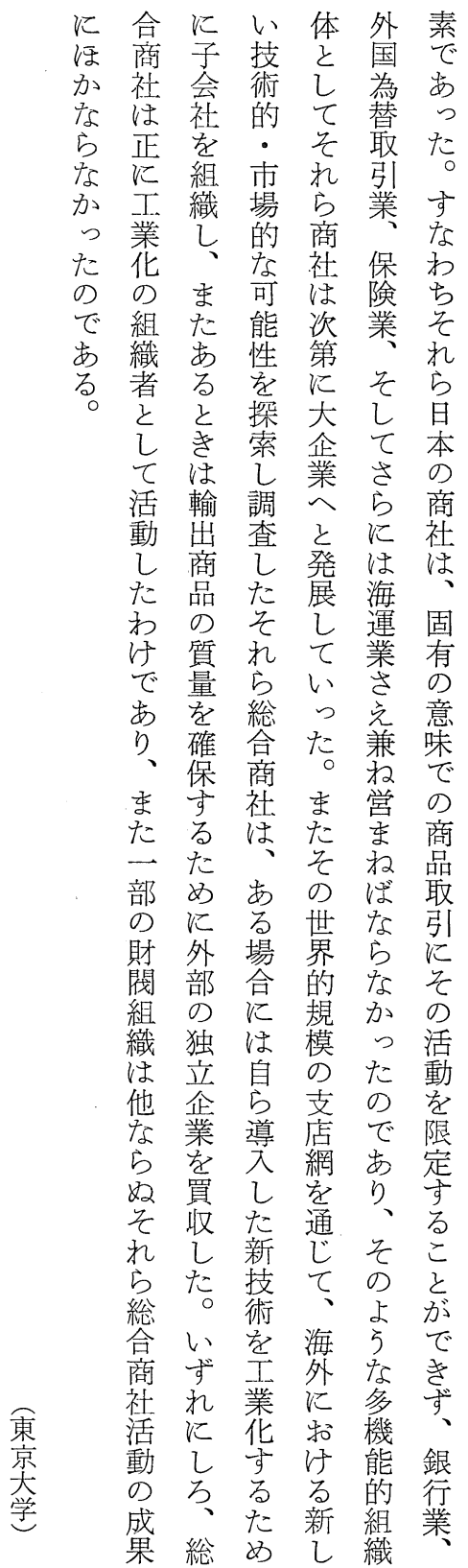




\title{
Organized Entrepreneurship in the Course of Industrialization of Pre-War Japan
}

\author{
by \\ Keiichiro Nakagawa \\ University of Tokyo
}

The gate into modern industrial society is generally narrower for the follower than for the leader countries. Moreover, to catch up with the leader countries, the late-comers must pass this narrow gate more rapidly than did leader countries. Various segments and sectors in a backward economy are inevitably juxtaposed and the narrow gate forces all elements and sectors in the national economy. Therefore, the Meiji entrepreneurs in the course of industrialization tended to think and act rather with a broad and national horizon, considering the problems of various levels, sectors and units of the national economy. In short, the Meiji entrepreneurs were unable to secure their private profit unless those aspects of social interactions-social gainswere deliberated simultaneously.

Such an organized aspect of Meiji entrepreneurship was particularly evident in foreign trade. Japan possessed no organization of foreign trade on the eve of industrialization. Therefore, the formation of powerful commercial enterprises had to precede the emergence of modern industrial production, and one of the results of such an evolution of commercial organization was the famous "general merchants" (sogoshosha), a unique feature in the modern industrial society of Japan. They had to perform the functions of bankers, exchange brokers, insurance brokers and sometimes even the function of shipping firms, and as such these multi-functional organizations gradually grew into big business. Through their world-wide network of branch offices, they explored the newest industrial techniques and surveyed market opportunities abroad. They proceeded at times to promote subsidiaries for the purpose of insustrial 
izing the technology they imported and sometimes they purchased independent factories to assure the quantity of goods they were to export. Thus they truly became industrial organizers on a large scale. The "Zaibatsu" organization was the result of such an organized entrepreneurship executed by genral merchants. 